by R.V. Gireesh ${ }^{1,2}$, Kowete-ü Sekhamo ${ }^{l}$ and M. Jayananda ${ }^{1}$

\title{
Anatomy of 2.57 - 2.52 Ga granitoid plutons in the eastern Dharwar craton, southern India: Implications for magma chamber processes and crustal evolution
}

\author{
1 Department of Geology, Centre of Advanced Studies, University of Delhi, Delhi - 110 007, India. E-mail: gireeshrv@gmail.com; \\ koweteu00@gmail.com; mjayan.geol@gmail.com \\ 2 Department of Geology, Bangalore University, Bangalore -560 056, India
}

We present results of field studies for magmatic processes of 2.57-2.52 Ga calc-alkaline plutonic bodies from three corridors in the eastern Dharwar craton (EDC) corresponding to different crustal levels. At deeper levels plutons are bounded by thick zone of migmatites with numerous melt filled shear bands which often overprinted by incipient charnockite. On the other hand in the mid-to-upper crustal levels plutons show relatively sharp contacts and truncates the adjoining basement. The plutons are composite which comprises voluminous intrusive monzodiorite, quartz-monzonite and porphyritic monzogranite in the central part and minor anatectic granites or diatexite at periphery. Numerous xenoliths, Mafic Magmatic Enclaves (MME), disrupted trains of synplutonic mafic dykes are found in both intrusive and anatectic facies. The plutons show magmatic as well as solid-state plastic fabrics defined by magmatic flow banding and C-S fabrics respectively. Crustal scale shear zone network comprising early melt filled NE trending hot ductile dextral shear bands and slightly later colder $N W$ trending sinistral shear bands defined by rotation of mafic boudins, phenocrysts and C-S fabrics. The internal architecture of plutons is attributed to the crustal scale magma chamber processes where voluminous intrusive magmas emplaced into the crust caused reworking of surrounding basement resulting in production of anatectic magmas. Crystallization of voluminous intrusive magmas in the deep crust probably caused development of fractures to mantle depth causing decompression melting of mantle and resultant mafic magmas penetrated the crystallizing host in magma chambers. Field evidences together with published ages and $\mathrm{Nd}$ isotope data reveal a spatial link between late
Archaean magmatic accretion, reworking and cratonization.

\section{Introduction}

In recent years, tremendous progress has been made in understanding the dynamics of magma chamber processes and pluton emplacement mechanisms by study of granitoid batholiths from different tectonic settings (Barbarin, 2005; Barnes et al., 2002; Castro, 1987; Frost and Mahood, 1987; Paterson et al., 1996, 2004; Santosh Kumar, 2010; Tobisch et al., 1997; Turnbull et al., 2010). A good synthesis on origin and geodynamic environments of different granitoid types has also been documented by Barbarin (1999). On the contrary only few studies have been focused on the internal structure and magma chamber processes of Archean and Proterozoic granitoid plutons (Chardon and Jayananda, 2008; Moyen et al., 2003a; Neves and Vauchez, 1995; Ramsay, 1989), while numerous contributions have presented a wealth of elemental and isotopic data (Halla, 2005; Heilimo et al., 2010; Jayananda et al., 2000, 2006; Martin et al., 2005; Moyen et al., 2003b, 2010; Sylvester, 1994 and references therein). Granitoid plutons are important constituents of Archaean cratons and occupy over 20 percent area of exposed felsic rocks. Study of their anatomy including relationship with surrounding TTG and greenstone belt is key to our understanding of fundamental architecture of Archaean cratons. Further, study of Archean granitoid plutons is crucial to address host of other issues such as magmatic accretion processes including dynamics of felsic magma chambers, interaction of coeval felsic and mafic magmas, crustal reworking together with their spatial link to regional deformation patterns and cratonization of Archaean crust. Most of the field studies on Archaean granite plutons generally dealt with structural patterns and thermo-mechanical aspects of their emplacement, their role in greenstone tectonics and cratonization (Brun, 1983; Chardon and Jayananda, 2008; Chardon et al., 2002, 2008; Chown et al., 2002; Cruden and Launeau, 1994). However, anatomy of these Archaean granitoid plutons including relationship between different facies of plutons, enclaves, xenoliths, synplutonic mafic dykes and interaction of coeval felsic and mafic magmas is poorly documented. The Eastern Dharwar Craton (EDC) in southern India (Fig.1) exposes a titled cross-section of crust with several N-S trending 2.57-2.52 Ga granitoid plutons (Chadwick et 
al., 2000; Jayananda et al., 2000, 2009; Chardon and Jayananda, 2008; Chardon et al., 2008; Moyen et al., 2003b) forms an ideal target to study crustal scale magmatic processes. Several petrological descriptions, zircon $\mathrm{U}-\mathrm{Pb}$ ages, geochemical and $\mathrm{Nd}-\mathrm{Sr}$ isotope data on the late Archean granitoid plutons show their derivation from juvenile source with minor influence of old continental crust (Bhaskar Rao et al., 1992; Balakrishnan et al., 1999; Chadwick et al., 2007; Chardon et al., 2002, 2008; Dey et al., 2012; Friend and Nutman, 1991; Harish Kumar et al., 2003; Jayananda et al., 1995, 2000, 2009; Krogstad et al., 1991; Moyen et al., 2001, 2003a; Nutman et al., 1996; Peucat et al 1993a; Prabhakar et al., 2009b; Rogers et al., 2007; Sarvothaman, 2001).

The tectonic context of magmatic accretion and continental growth in the EDC is still a topic of much discussion and lively debate. Both Uniformitarian model (Krogstad et al., 1989, 1995; Moyen et al., 2003b; Dey et al., 2012) as well as Non-uniformitarian models (Jayananda et al., 2000) together with combined two stage model (Harish Kumar et al., 2003) have been proposed. Most of the above models are mainly based on petrological and geochemical data and only few models consider field based structural data (e.g. Chadwick et al., 2000, 2007; Choukroune et al., 1994; Chardon et al., 2008, 2011). Models invoking lateral accretion in arc settings propose generation of juvenile magmas either by melting of subducting oceanic slab or melting of mantle wedge to explain the granitoid plutons and intervening volcanic arcs. Chadwick et al (2000) have considered the calc-alkaline granitoid plutons and intervening volcanic arcs as Dharwar batholith formed during 2.7-2.5 Ga oblique convergence in the transpressional context. On the contrary, Jayananda et al (2000) explained 2.55-2.5 Ga magmatism by mantle plume impact below the presently exposed level of Closepet granite where melting of enriched mantle hotspot generated enriched juvenile magmas whilst to the east plume causes melting of chondritic to depleted mantle producing less enriched or depleted calc-alkaline magmas. The heat and volatiles associated with newly generated juvenile magmas cause remelting of surrounding crust during their emplacement which explains the origin of anatectic granites.

Harish Kumar et al (2003) proposed a two stage model involving subduction of oceanic crust followed by plume impact. These authors explain calc-alkaline juvenile magmatism by melting of oceanic slab in subduction zone and explain reworking juvenile crust and associated high-T and low pressure granulite metamorphism by a plume impact.

On the other hand integrated studies involving detailed strain fabrics data and kinematic analysis together with $\mathrm{U}-\mathrm{Pb}$ zircon geochronology in the Dharwar craton by Chardon and Jayananda (2008) and Chardon et al $(2002,2008)$ reveal contrasting responses of two cratonic blocks for latest Archaean (2.57-2.5 Ga) shortening. The rigid colder ancient crust in WDC have undergone moderate shortening and strain localized in widely spaced shear zones whilst the voluminous hot young juvenile crust in EDC responded to shortening by flowing laterally against WDC (Chardon et al., 2008). More recent combined structural analysis and zircon dating in EDC by Chardon et al (2011) show synconvergence lateral flow of hot orogenic crust during latest Archaean (2.56-2.5 Ga) juvenile accretion implying 3D mass redistribution of viscous lower crust submitted to convergence and efficiently compensates topographic relief at shallow crustal level.

Although several petrological, geochemical and structural studies were conducted on granitoids to characterize their sources and time relationship with regional shear deformation. However, no major attempt has been made to study the anatomy of plutons, dynamics of magma chamber processes and time relationships of different facies with respect to crustal reworking, regional deformation patterns and cratonization of Archaean crust in the Dharwar craton. This contribution presents an overview of anatomy of the granitoid plutons at different crustal levels with particular emphasis to characterize magma chamber processes including interaction of coeval felsic and mafic magmas, their spatial relationship, regional deformation and metamorphic patterns within the geological framework of the EDC. Finally by integrating our field data with published isotopic data we discuss tectonic context of Neoarchaean calc-alkaline magmatic accretion and its spatial link to crustal reworking and cratonization.

\section{Regional Geology}

The Dharwar craton, southern India corresponds to a large oblique section of Archaean continental crust with protracted crustal history from 3.6 to $2.5 \mathrm{Ga}$ and forms a major wide hot orogen during end Neoarchaean (Chardon et al., 2011). The craton comprises vast areas of polyphase TTG-type gneisses regionally known as peninsular gneisses, two generations of volcanic-sedimentary greenstone sequences (older Sargur Group and younger Dharwar Supergroup) and 3.0 Ga, 2.62 Ga and 2.57-2.50 Ga calc-alkaline to high-K granitoid plutons. The craton is generally divided into two crustal blocks viz., western Dharwar craton (WDC) and eastern Dharwar craton (EDC) based on crustal thickness, abundance of TTG-greenstones- granites, structure and metamorphic patterns (Chadwick et al., 2000; Chardon et al., 2008, 2011; Drury, 1983; Jayananda et al., 2006; Swaminath et al., 1976). The steep mylonitic shear zone along the eastern boundary of the Chitradurga belt is considered as the dividing line between the two crustal blocks (Drury, 1983; Jayananda et al., 2006; Chardon et al., 2011).

The basement in the western Dharwar craton comprises abundant TTG gneisses with interlayered Sargur Group greenstone basins. Published geochronologic and Nd isotope data of TTG indicate 3.43.2 Ga for the emplacement of their magmatic protoliths (Bhaskar Rao et al., 2008; Meen et al., 1992; Peucat et al., 1993a). The Sargur Group comprises 3.38-3.0 Ga komatiite-basalt-felsic volcanic rocks with interlayered quartzite-pelite-carbonate-BIF association (Bhaskar Rao et al., 2000; Jayananda et al., 2008; Peucat et al., 1995). Detrital zircons from the sediments indicate $3.63-3.23 \mathrm{Ga}$ for their provenance (Nutman et al., 1992; Bhaskar Rao et al., 2008). The TTG-Sargur Group greenstones are unconformably overlain by the younger (2.91-2.67 Ga) Dharwar Supergroup greenstone basins which begins with basal conglomerate/quartzite followed by basaltintermediate to felsic volcanic flows with carbonate-argillitegreywacke sequences and thick banded iron formations forms the summit (Anil Kumar et al., 1996; Jayananda et al., 2011; Nutman et al., 1996; Trendall et al., 1997a). Largely mylonitic high potassic 3.0 Ga Bukkapatna granite pluton found along the eastern boundary of Chitradurga belt within the boundary shear zone (Chardon et al., 2011) whilst several 2.62 Ga high-K plutons intrude either TTGSargur Group basement or Dharwar Supergroup greenstone basins in the western Dharwar craton (Jayananda et al., 2006; Chadwick et al., 2007). Metamorphic mineral assemblages (kyanite-garnetstaurolite-chloritoid) from south central part of WDC indicate pressures close to 6-8 $\mathrm{Kb}$ and $550-700^{\circ} \mathrm{C}$ (Bouhallier, 1995). Domebasin patterns, sagducting greenstone ridges with broadly spaced regional shear zones are the dominant structures documented in the 


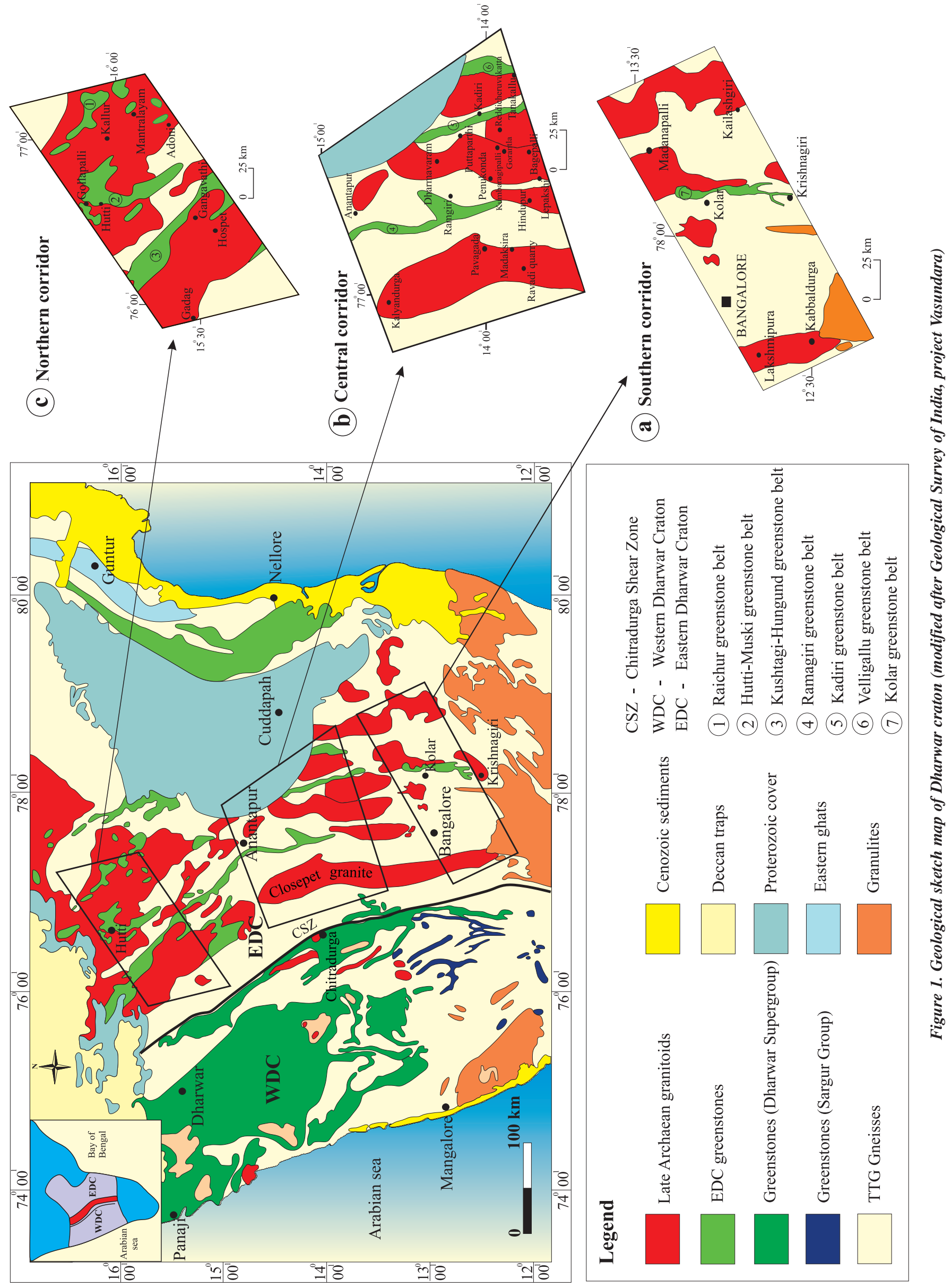


WDC which have been interpreted as result of gravitational collapse of unstable crust associated with major episodes of accretion (Bouhallier et al., 1993, 1995; Bouhallier, 1995; Chardon et al., 1996, 1998, 2008).

The Archaean basement in the EDC comprises mainly $2.7 \mathrm{Ga}$ tonalitic to granodioritic gneisses with large remnants of 3.0-3.38 Ga TTG with interlayered Sargur-type greenstones (mostly occur as discontinuous 4-6 km long bands confined to the southwestern part of EDC), 2.7 - $2.54 \mathrm{Ga}$ volcanic-dominated greenstone belts and 2.57-2.52 Ga most voluminous N-S trending calc-alkaline plutonic belts (Balakrishnan et al., 1990, 1999; Chadwick et al., 1999, 2000; Chardon et al., 2008; Dey et al., 2012; Jayananda et al., 2000, 2012; Friend and Nutman 1992; Nutman et al., 1996). The most spectacular of these plutonic belts is the $400 \mathrm{~km} \mathrm{~N}-\mathrm{S}$ trending Closepet granite which traverses large part of the EDC. The basement TTG was involved in reworking event close to $2.52 \mathrm{Ga}$ which is spatially linked to major juvenile magmatic accretion and regional shear deformation (Chardon et al., 2008; Jayananda et al., 1995, 2000; Krogstad et al., 1995). The EDC is affected by low pressure and high-T metamorphism with preserved assemblages corresponding to a progressive transition amphibolite facies to granulite facies (Janardhan et al., 1982) which was dated at ca. 2.5 Ga (Mahabaleswar et al., 1995; Peucat et al., 1993a; Mojzis et al., 2003). More recently an earlier $2.62 \mathrm{Ga}$ granulite facies close UHT conditions has been documented from the central part of EDC (Jayananda et al., 2011). The EDC traversed by closely spaced regional shear zones which trends NNE in the south and NNW in the north (Chardon et al., 2008). Spectacular flat fabrics in the $2.56 \mathrm{Ga}$ tonalitic gneisses in the central part of EDC attributed to longitudinal flow of hot juvenile crust during end Archaean accretion in a wide hot orogen (Chardon et al., 2011).

\section{Geology of the granitoid plutons in the regional corridors across the EDC}

The late Archaean granitoid plutons and surrounding basement is the object of the present study. Three roughly E-W corridors selected in this study corresponding to different crustal levels in the EDC (Fig. 1). Granitoid plutons in all the three selected corridors are bounded by TTG basement and volcanic-dominated 2.7-2.54 Ga greenstone belts (Jayananda et al., 2012).

\section{Southern corridor}

The southern corridor lies within the amphibolite - granulite facies transition zone in the EDC (Fig. 1a) which corresponds to deepest exposed level of plutons (Chardon et al., 2008; Jayananda et al., 2009; Moyen et al., 2003a). Here volume of granite is less compared to the central and northern corridor. Our work is focused on a crustal corridor covering Kabbaldurga-Magadi in the west to Krishnagiri-Madanapalli in the east (see Fig. 1a). Here plutons show diffuse contacts with the adjoining migmatitic TTG basement and surrounded by a wide zone of metatexites as well as diatexites (Harish Kumar et al., 2003; Chardon and Jayananda, 2008; Jayananda et al., 1995, 2000; Moyen et al., 2003a). The migmatitic TTG along the western part of corridor in the Kabbaldurga-Bangalore section have been dated 3.14-2.96 Ga (Friend and Nutman, 1992; Jayananda et al., 2000) whilst the juvenile tonalitic to granodioritic basement in the eastern part of the corridor has been dated at $2571 \pm 5 \mathrm{Ma}$ and $2535 \pm 5 \mathrm{Ma}$ (Peucat et al., 1993a) with remnants of TTG as old as $3277 \pm 5$ Ma in Kolar area (Chardon et al., 2002). U-Pb zircon data of the anatectic component of the Closepet granite indicates $2513 \pm 5$ Ma (Friend and Nutman, 1992) whilst the intrusive component indicates $2518 \pm 5 \mathrm{Ma}$ (Jayananda et al., 1995). Around Bangalore the plutons indicate zircon U-Pb ages of $2540 \pm 5 \mathrm{Ma}$ and further east towards Kolar-Krishnagiri area zircon ages define $2557 \pm 5$ to $2534 \pm 6$ Ma for the emplacement of plutons (Jayananda et al., 2000; Chardon et al., 2002; Peucat et al., 1993a).

The plutons are composite and contain two major magmatic suites including voluminous intrusive facies and the anatectic granite as well as diatexitic facies surrounding them. The intrusive facies comprises of clinopyroxene-amphibole bearing dark grey monzodiorite to quartz-monzonite, porphyritic monzogranite and grey granodioritic rocks whilst the anatectic facies include pink to light grey granites. In the deepest level the intrusive facies found as sheets or dykes traversing the basement gneisses. The volume of intrusive facies progressively increases to the northern part of southern corridor in Magadi - Madanapalli area where inselburgs are mainly composed of porphyritic monzogranites and quartz-monzonites. Diatexites are abundant which show progressive evolution to inhomogeneous granite with abundant biotite schlieren and eventually to homogeneous granite. Diatexites frequently contain boudins/enclaves of intrusive facies (Fig. 2). The intrusive facies contain recrystallized areas with large crystals of amphibole and/or clinopyroxene close to the veins of anatectic granite which could be attributed to the interaction of fluid associated with anatectic granite (Fig. 3). The whole southern corridor contain anatomizing network of shear zones which include an earlier $\mathrm{N} 10-25^{\circ} \mathrm{E}$ trending syn-melt dextral shear bands (Fig. 4) and a later $\mathrm{N} 10-20^{\circ} \mathrm{W}$ trending sinistral shear bands containing numerous mafic enclaves and rotated angular mafic to ultramafic xenoliths with strong fabrics (Fig. 5). The intrusive facies of the plutons show magmatic as well as tectonic fabrics. Magmatic foliation is characterized by magmatic flow banding and alignment of feldspars (Fig. 6). The anatectic facies show magmatic flow fabrics with oriented small biotite schlieren and alignment of fragments of intrusive quartzmonzonite defining flow direction (Fig. 7). The intrusive and anatectic facies often show diffused contact or sharp contact with reaction rim indicating short time gap or emplacement of anatectic facies when the intrusive facies were in advanced stage of crystallization. Major sinistral shear zones are confined to the boundary of the plutons which contain numerous mafic to ultramafic and also traverse the plutons.

Numerous sub-rounded mafic magmatic enclaves (MME) are found in the intrusive facies whilst anatectic facies contain disrupted boudins or fragments of synplutonic mafic dykes (Fig. 8 and 9). Frequently mafic enclaves and xenoliths are broken where recrystallization of mafic enclaves and xenoliths lead to the formation of large concentration amphiboles with occasional clinopyroxene rimmed with amphibole.

Arrested charnockite development with prograde reaction producing orthopyroxene on the migmatitic gneisses, anatectic as well as intrusive facies is the most striking features of the southern corridor (Fig. 10). Charnockite development is mainly confined to steep fabrics along the conjugate shear bands that traverse the migmatites, intrusive as well anatectic facies (Chardon and Jayananda, 2008). Such arrested charnockite formation has been explained by $\mathrm{CO}_{2}$-rich fluid streaming causing dehydration in the hotter deep crust (Janardhan et al., 1982). $\mathrm{U}-\mathrm{Pb}$ monazite dating of charnockite formation indicate $2507 \pm 5 \mathrm{Ma}$

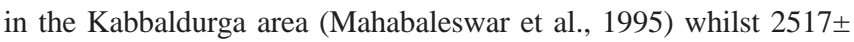
5 Ma in Krishnagiri area (Peucat et al., 1993a). 

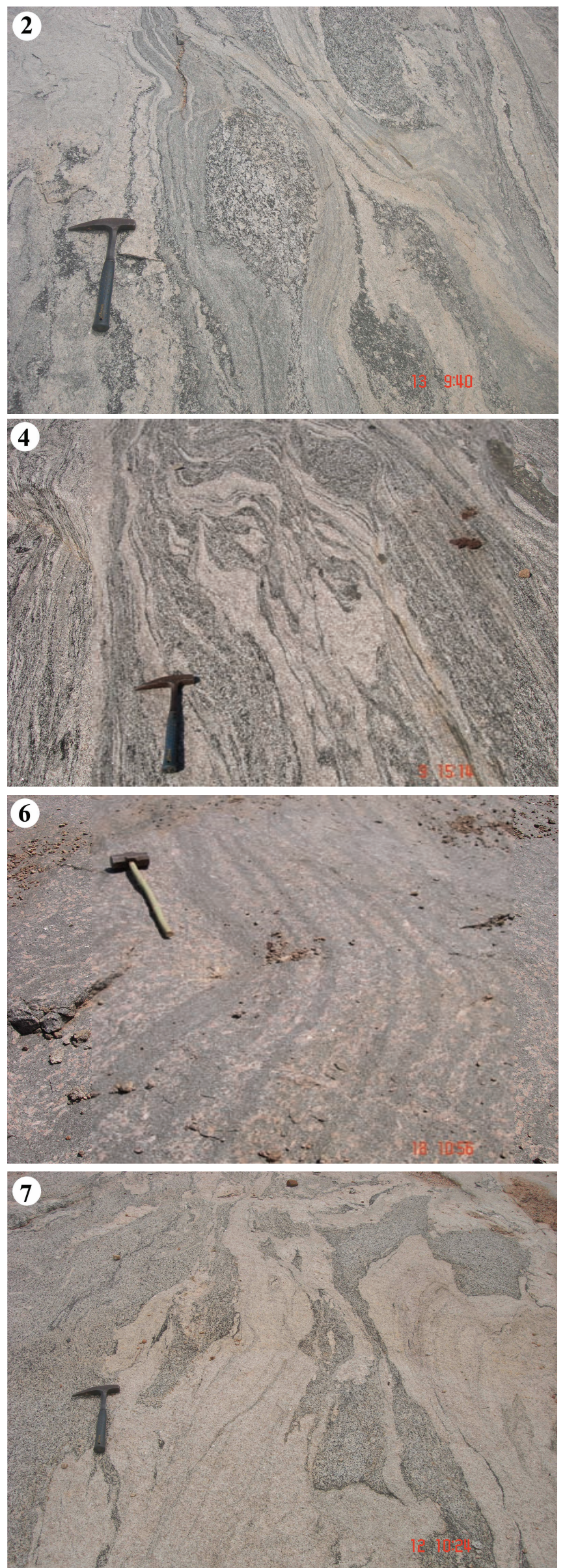
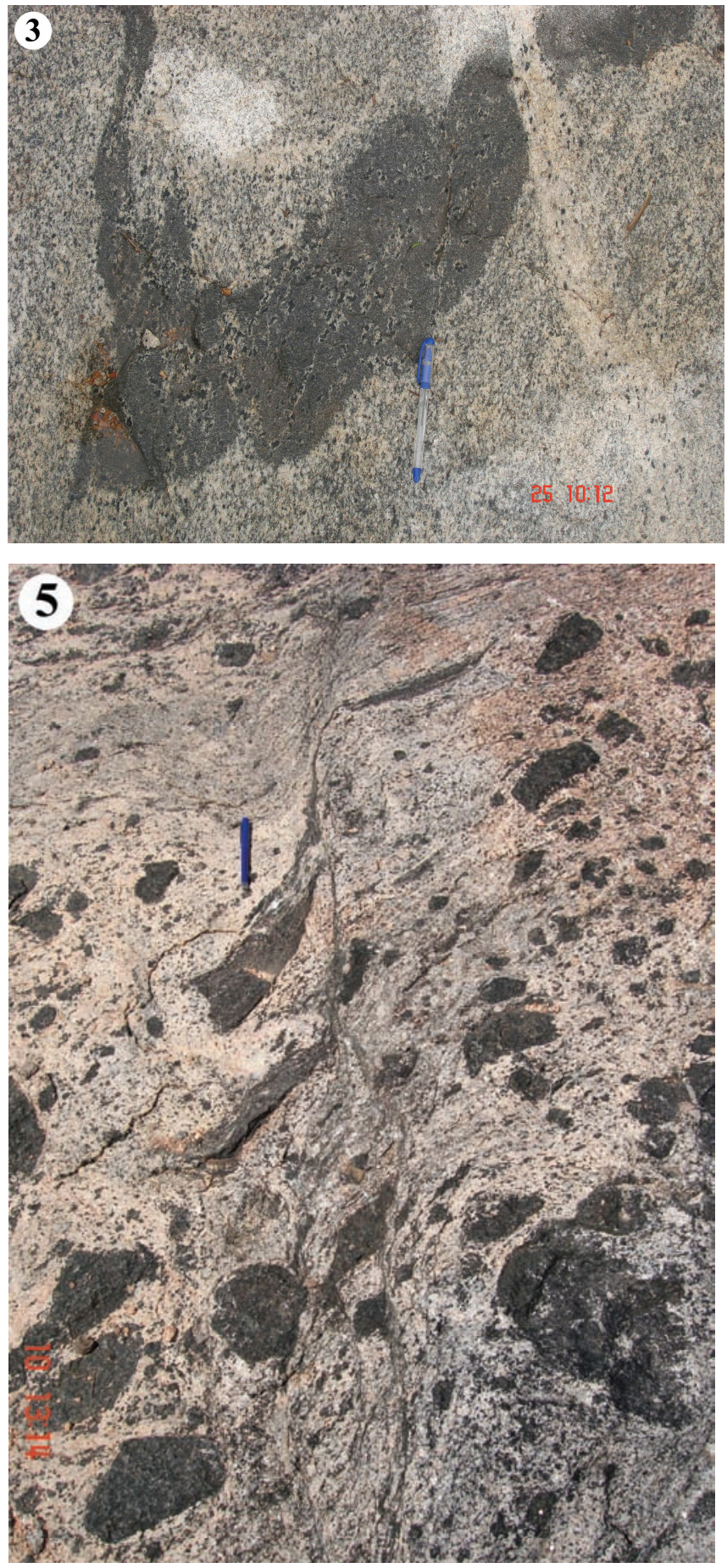

Figs(2-7). 2 - Diatexites contain the boudins of porphyritic monzogranite from a large quarry about $5 \mathrm{~km}$ north of Madanapalli in Anantapur road. 3 - Quartz-monzonite contains large crystals of amphibole and/or clinopyroxene along the anatectic veins. 4-Melt filled $\mathrm{N}^{\circ} \mathrm{E}$ trending dextral shear bands from a large quarry exposure about $6 \mathrm{~km}$ east of Krishnagiri in Chennai road. $5-N 18^{\circ} \mathrm{W}$ trending sinistral shear containing rotated mafic boudins at quarry exposure near Kailashgiri in Vaniyambadi - Peranampattu road. 6 - Dark grey quartz-monzonite and porphyritic monzogranite together define magmatic flow banding at a quarry $N E$ of Lakshmipura in Ramanagaram-Magadi road. 7 - Anatectic facies define magmatic flow fabrics with fragments of intrusive quartz-monzonite at quarry near $27 \mathrm{~km}$ from Mudivedu in Gollapalli road. 

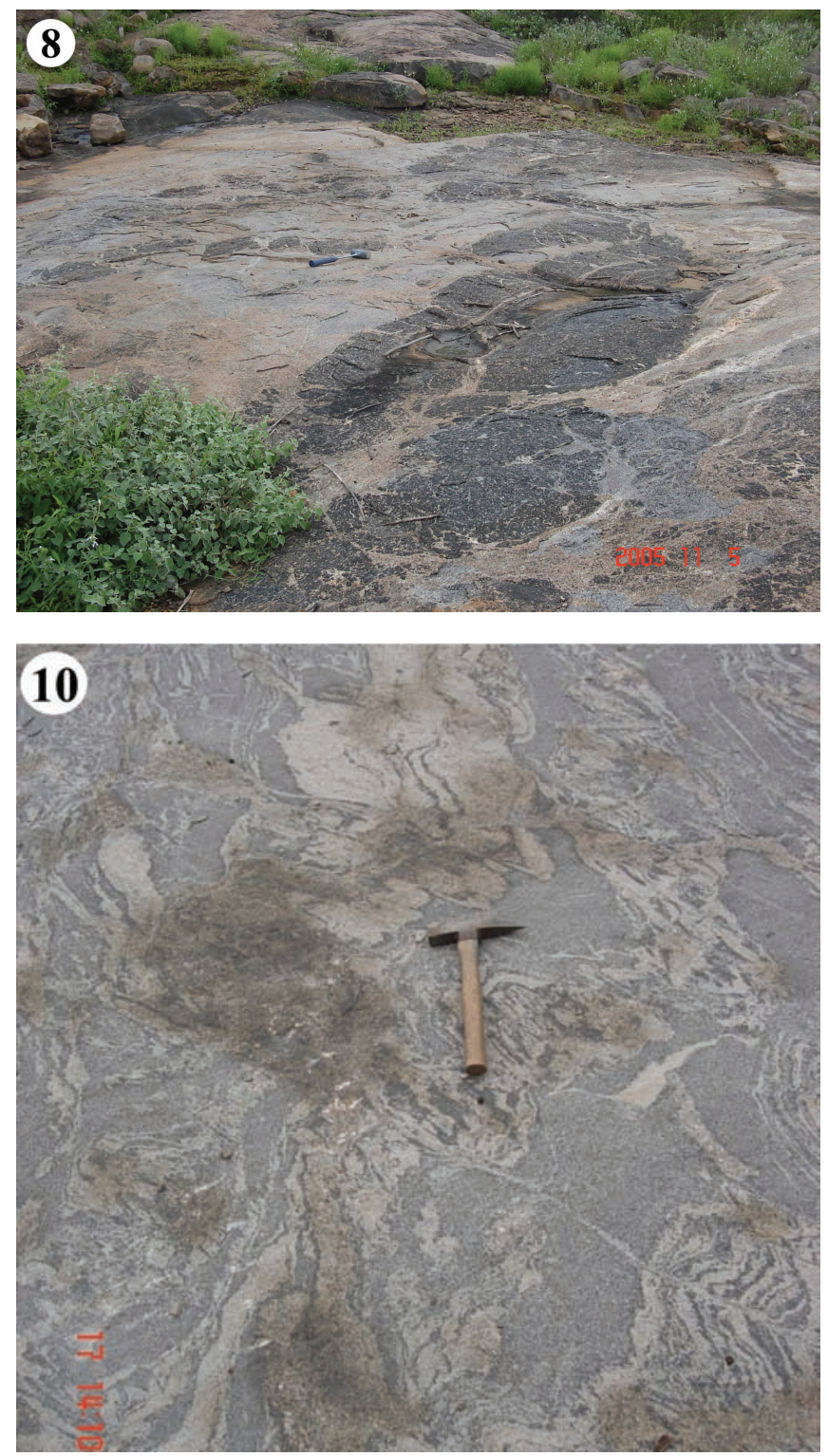

To summarize, the southern corridor expose the deepest crustal levels with relatively thin granitoid bodies with large screens migmatized basement gneisses, fragmented synplutonic mafic dykes and numerous melt filled shear zones.

\section{Central corridor}

The central corridor corresponds to zone of accumulation of granitoid magmas and plutons are voluminous and widest. This corridor covers granitoid plutons of the Closepet granite, LepakshiBukkapatnam, Anantapur-Gooty and Kadiri-Rayachoti areas (Fig. 1b). The plutons are widest in this corridor which shows relatively sharp contacts with the adjoining basement. This corridor also includes three prominent greenstone belts including Ramagiri-Penakacherla, Kadiri and Veligallu belt. The basement mainly forms low-lying areas with ground level exposures whilst plutons generally form inselberg topography with tors or flat tops. The basement comprises two major types of lithologies viz. minor screens of migmatitic TTG which mainly occur in the western part of the corridor and rare or absent in the eastern part. Few small discontinuous exposures of high grade pelitic

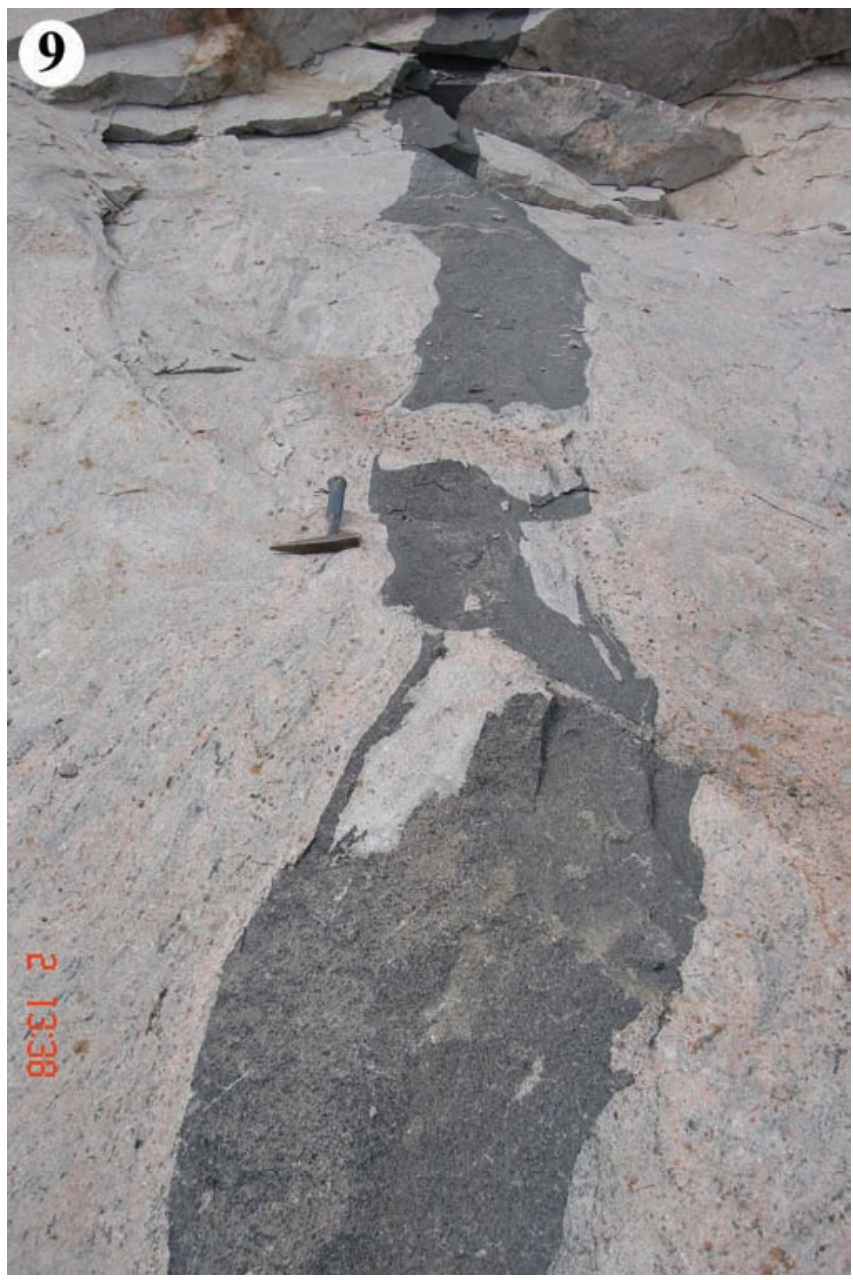

Figures 8-10. 8-Disrupted sub-rounded to pillow shaped boudins of synplutonic mafic dyke in anatectic facies near Edurkottai village about $8 \mathrm{~km}$ SE of Krishnagiri. 9 - Fragmented synplutonic dyke from Kabbaldurga quarry at the southern tip of the Closepet granite. 10 - Arrested charnockite formation on anatectic facies and migmatitic grey gneiss at Kabbaldurga quarry

assemblages corresponding to granulite facies or close ultra-high temperature conditions $\left(850^{\circ} \mathrm{C}\right.$ and $5 \mathrm{~kb}$ ) found in a NE trending shear zone along the eastern boundary of Closepet granite (Jayananda et al., 2011). On the other hand strongly banded tonalitic to granodioritic gneisses are abundant. Zircon U-Pb SHRIMP dating of these migmatitic gneisses from western boundary of the Closepet granite indicate ages in the range of 3222-3255 Ma, 3301-3360 Ma (Jayananda unpub. data). The banded tonalitic to granodioritic gneisses in the vicinity Ramagiri schist belt indicates $\mathrm{U}-\mathrm{Pb}$ zircon age of $2650 \pm 7 \mathrm{Ma}$ (Balakrishnan et al., 1999). The narrow thin $\mathrm{N}-\mathrm{S}$ trending greenstone belts are dominated by volcanic rocks with basalts in the lower levels and felsic volcanics flows or pyroclastics in the higher stratigraphic levels. U-Pb zircon dating of zircon from pyroclastic rocks in the central part of the Ramagiri greenstone belt yielded an age of $2707 \pm 18 \mathrm{Ma}$ (Balakrishnan et al., 1999) whilst SHRIMP U-Pb dating of zircon from rhyolite from Veligallu belt define $2690 \pm 7 \mathrm{Ma}$, whilst $2551 \pm 10 \mathrm{Ma}$ for the felsic volcanics of Kadiri greenstone belt (Jayananda et al., 2012). This clearly suggests bimodal age distribution of greenstone volcanics in the EDC. 
Plutons are composite which comprise two magmatic suites viz. most voluminous intrusive facies and minor anatectic facies with numerous mafic xenoliths, MME and fragmented / boudinaged synplutonic mafic dykes. The intrusive facies include most abundant porphyritic monzogranite with sub-ordinate amphibole-rich dark grey quartz-monzonite. Occasionally large fragments or sub-rounded enclaves of dark grey monzodiorite occurs in association with porphyritic facies (e.g Pavagada quarry). Both porphyritic monzogranite and quartz-monzonite appears to be coeval as they are interlayered and often show diffusive contacts (Fig. 11). In some instances, the intrusive facies is traversed by anatectic facies particularly close to the periphery of the plutons. The intrusive facies
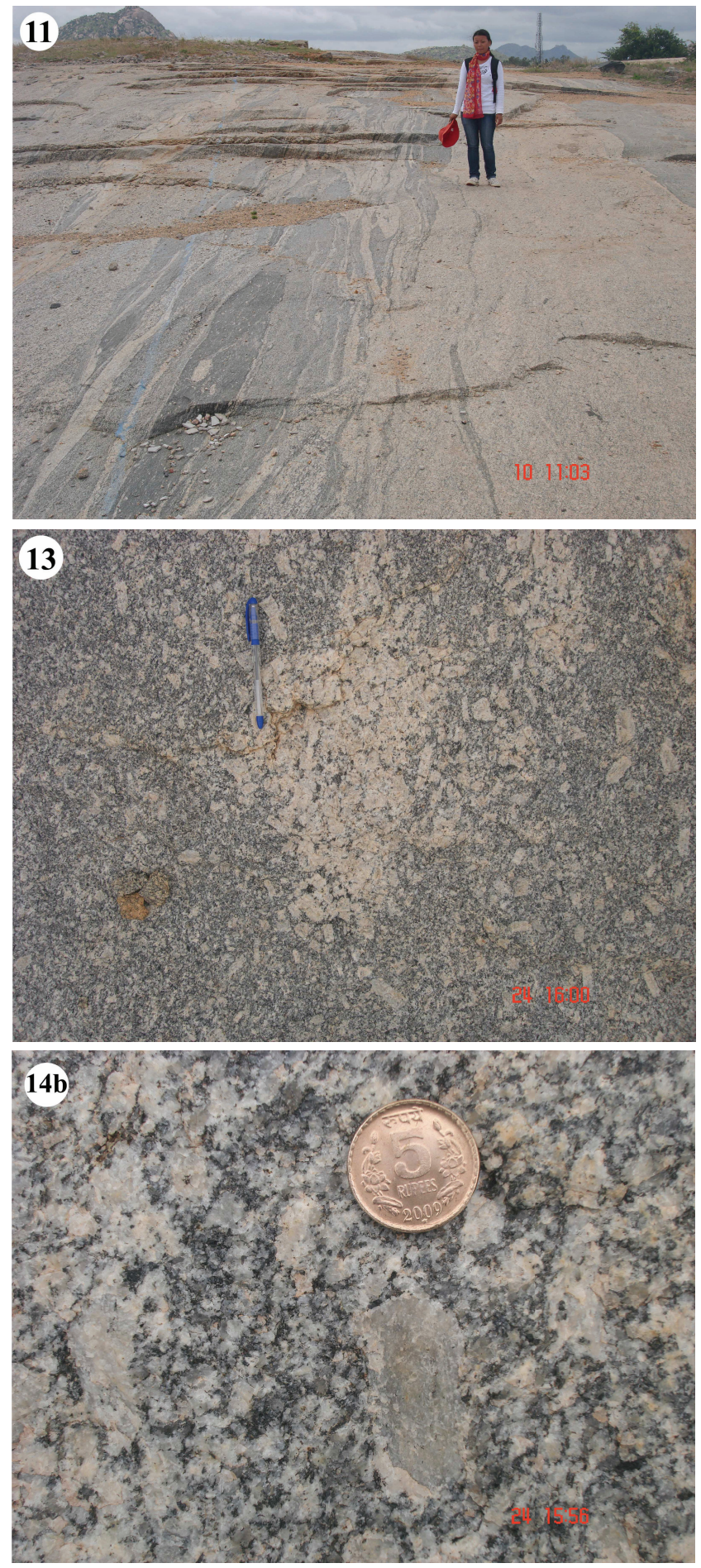

occasionally show magmatic banding and flow structures defined by alignment of feldspar phenocrysts or amphibole crystals but generally show plastic fabrics defined by stretched phenocrysts (Fig. 12). Cream to light pink colored phenocrysts constitutes $40-50 \%$ and at places their accumulation indicates possible filter pressing processes during emplacement (Fig. 13). Frequently phenocrysts show crude zoning and also in some instances exhibit rapakivi texture or orbicular structure (Fig. 14a and b). Rounded to elliptical MME are found mainly in porphyritic monzogranite where phenocrysts developed within MME indicating their co-magmatic stage (Fig. 15). In general, intrusive facies show good solid-state crystal-plastic structures such as $\mathrm{S}-\mathrm{C}$ fabrics which indicate mainly sinistral sense or occasional
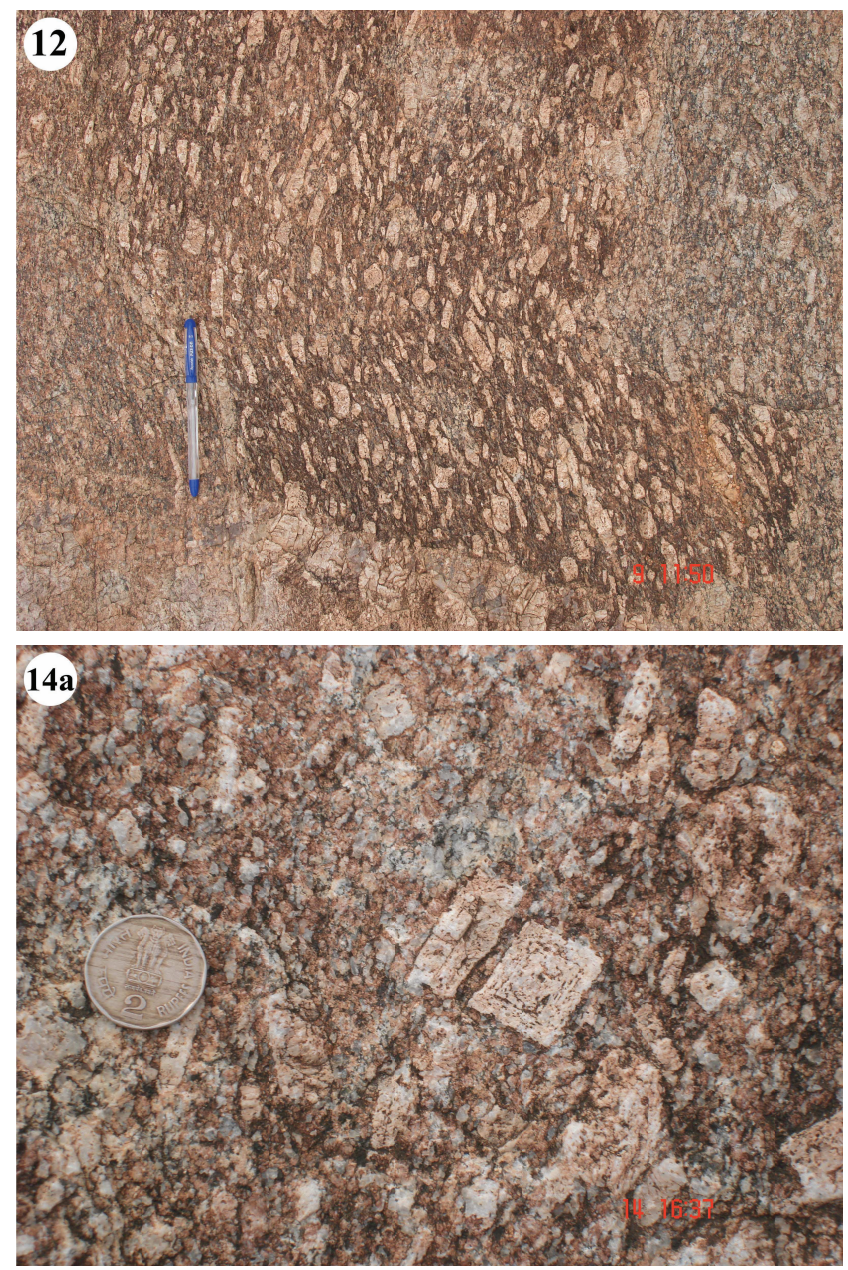

Figures 11-14. 11 - Anatectic and intrusive facies show diffuse contacts at a large quarry near V.E.S School in Pavagada town. 12 - Stretched and rotated phenocrysts indicating right lateral sense of displacement at about $1 \mathrm{~km} S$ of Billuru near Bagepalli. 13 - Phenocrysts accumulation in porphyritic monzogranite about $3 \mathrm{~km} \mathrm{~N}$ of Kumbaragipalli cross in Puttaparthi road. $14 a-K$-feldspar phenocrysts show crude zoning $1 \mathrm{~km}$ before Reddicheruvukatta in Kadiri-Gorantla road. 14 b - Phenocryst showing crude rapakivi texture $\sim 3 \mathrm{~km}$ north of Kodikonda cross. 
dextral sense of displacement (Fig. 16). The quartz-monzonite often interlayered with porphyritic facies where biotite-rich reaction rim indicate contrasting temperature of magmas (Fig. 17). They also occur as large angular enclaves in anatectic granites (Fig. 18). Coarse grained amphibole-rich dark grey quartz-monzonite found as continuous sheets of over $20 \mathrm{~km}$ along the western boundary of the Kadiri greenstone belt.
In the central corridor, anatectic facies evolve into more homogeneous granite with occasional biotite schlieren or thin partially disintegrated remnants of basement (Fig. 19). The anatectic facies include coarse grained pink to light grey granites confined to periphery of individual plutons. They often found along the foliation of intrusive facies and also occasionally magmatic flow boudinage the intrusive facies. Numerous mafic enclaves, migmatitic TTG and angular blocks
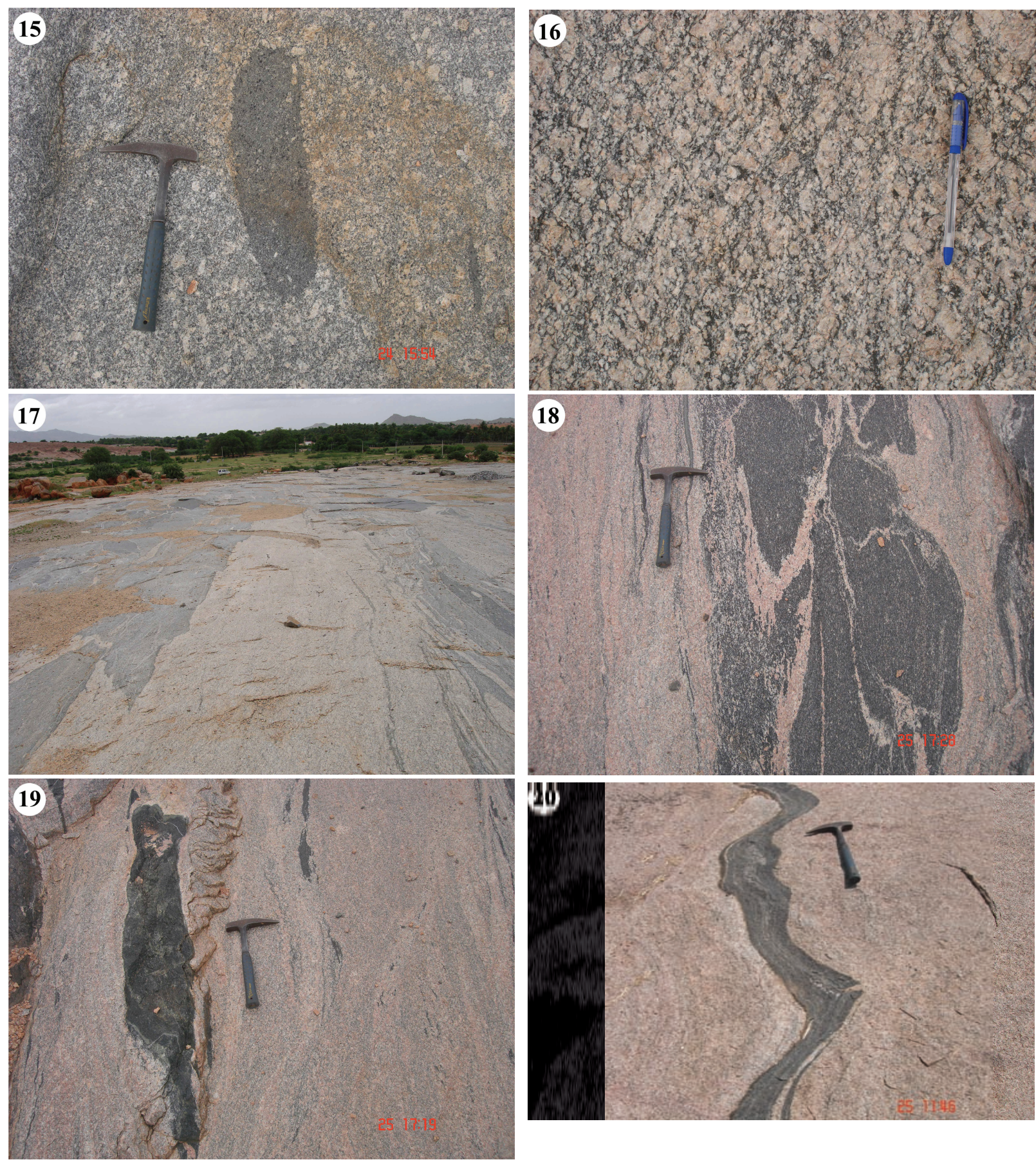

Figures 15-20. 15 - K-feldspar phenocrysts in MME at $\sim 3 \mathrm{~km} \mathrm{~N}$ of Kumbaragipalli cross in Puttaparthi road. $16-S-C$ fabric in porphyritic monzogranite near V.E.S School in Pavagada town. 17 - Diffuse contact between porphyritic monzogranite and quartz-monzonite at a quarry near V.E.S School in Pavagada town. 18 - Large enclaves of dark grey quartz-monzonite in anatectic pink granite from a quarry $5 \mathrm{~km}$ from Kalyandurga in Bellary road. 19 - Remnant of basement in anatectic pink granite at large quarry $5 \mathrm{~km}$ north of Kalyandurga in Bellary road. 20 - Anatectic pink granite and synplutonic mafic dyke define magmatic flow fabrics about $7 \mathrm{~km}$ north of Madakasira in Pavagada road. 

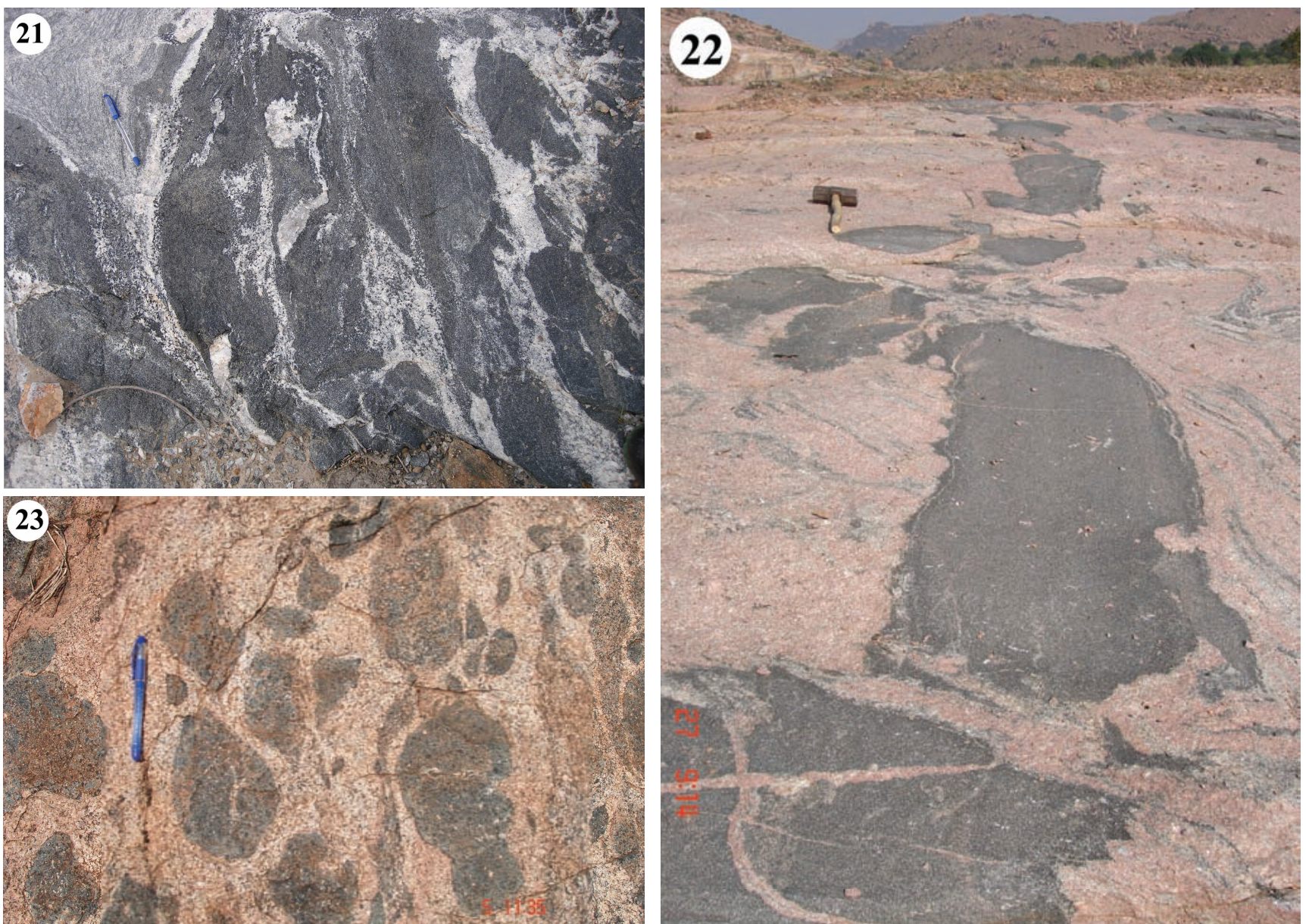

Figures 21-23. 21 - Anatomising anatectic veins with hornblende-clinopyroxene in mafic boudins at Ravadi quarry about $10 \mathrm{~km}$ north of Agali. 22 - Oriented MME to dismembered synplutonic mafic dyke from quarry about $3 \mathrm{~km}$ from Pavagada in Hindupur road. 23 -Rounded hybrid MME in pink granites showing interaction with anatectic pink granite magma flow zone in the southern outskirts of Tanakallu in Kadiri-Anantapur road

of rotated xenoliths are common. In the eastern boundary of the Closepet granite, pink anatectic granite together with spectacular synplutonic mafic dykes define magmatic flow structure (Fig. 20). Frequently volatile-rich anatectic veins inject as anatomizing network of coarse grained veins into huge basement mafic enclaves causing disruption where reaction leads to growth of huge amphibole as well as fluorite crystals in granite veins (Fig. 21).

Numerous enclaves including MME, basement gneisses and xenoliths of varying shapes and dimensions are found in both intrusive and anatectic facies, particularly abundant along the periphery of the plutons. Several spectacular fragmented or rarely continuous synplutonic mafic dykes found mainly along the periphery of the plutons. A progressive transition from oriented MME to fragmented synplutonic mafic dykes or even to nearly continuous dyke can be seen (Fig. 22). Numerous fine grained to porphyritic synplutonic mafic dykes often fragmented also traverse the intrusive facies which show sharp to diffuse contacts with host. Back-veining of leucocratic melts are common in synplutonic mafic dykes. This phenomenon can be attributed to reversal of crystallization of host granitoid magma caused by heat advection of mafic magma pulse and resultant leucocratic melts in turn penetrates the crystallizing mafic magma. South east of Kadiri near Tanakallu village numerous rounded to pillowed MME with pink granite found along the boundary between large synplutonic gabbroic dyke and the pink granite indicate magma mingling process
(Fig. 23). MME and the host granite show similar fabrics with diffusive contacts with progressive mingling and hybridization. In hybrid zones fine grained darkest grey MME appears to be more primitive corresponding to original melt composition compared to coarse grained dark grey MME which evolved and contain amphibole and feldspars.

In summary granitoid magmas accumulate and emplace into larger homogeneous plutonic bodies displaying different stages of magmatic flow to solid-state structures. The host granitoid magmas and mafic injections show interactions including mingling, mixing and hybridization.

\section{Northern corridor}

This corridor (Fig. 1c) corresponds to the higher crustal levels (Moyen et al., 2003a) that contain elongated NNW trending greenstone belts, minor TTG and most voluminous granite intrusions with synplutonic mafic dykes (Anand and Balakrishnan, 2010; Chadwick et al., 2000; Jayananda et al., 2009; Prabhakar et al., 2009a).

The greenstone belts include Kustagi-Hungund, Hutti-Maski, Raichur, Gadwal and Narayanapet comprising dominantly of basalts with minor boninitic to intermediate volcanic rocks and adakites (Manikyamba et al., 2009 and references therein; Naqvi et al., 2006). Whole rock $\mathrm{Pb}-\mathrm{Pb}$ isochron of metabasalts define an isochron age of 
$2706 \pm 130 \mathrm{Ma}$ (Anand and Balakrishnan, 2010) whilst SHRIMP U$\mathrm{Pb}$ zircon dating of felsic volcanic from Hutti greenstone belt indicate 2586 \pm 59 Ma (Jayananda et al., 2012; Rogers et al., 2007) suggesting bimodal age distribution of the greenstone succession. Basement gneisses are confined to the low lying areas in between plutonic belts. Two types of gneisses occur in this crustal domain which includes viz. highly migmatitic TTG with mafic layers and boudinaged leucocratic veins generally occur as large enclaves in the high strain zones close to the periphery of the plutons (Fig. 24) and strongly banded dark grey tonalitic facies cut by anatectic granites widespread throughout the northern corridor (Fig. 25). Isotopic age data on gneisses is poor and preliminary $\mathrm{U}-\mathrm{Pb}$ zircon data indicate ages around 2.7 Ga (Jayananda unpub. data). The plutons generally found as low lying bouldary exposures in the western part whilst frequently as stocks in the eastern part showing sharp contact with the surrounding basement. SHRIMP U-Pb zircon data of Kavital porphyritic granodiorite from Hutti indicate $2543 \pm 39$ Ma (Rogers et al., 2007). On the other hand, zircons from clasts of granodiorites in the Palakanmardi conglomerate from the Hutti schist belt define SHRIMP $\mathrm{U}-\mathrm{Pb}$ age of $2576 \pm 12 \mathrm{Ma}$ which has been interpreted as magmatic stage of erosional provenance (Vasudev et al., 2000). These granitoid plutons are generally bounded by major NNW trending shear zones along their periphery (Chardon et al., 2008) or high strain zones (Chadwick et al., 2000) characterized by progressive increase in strain to the periphery of plutons leading to development of mylonitic fabrics. The important feature is that the anatectic facies are homogeneous as well as abundant. They comprise dominant pink to light grey granite facies. On the other hand the intrusive facies comprise voluminous granodiorite with minor quartz monzonite and porphyritic monzogranite. The anatectic facies and intrusive facies are often interlayered with diffuse contacts indicating their comagmatic nature. Discrete bodies of diorites or fine grained intermediate rocks emplaced in sub-volcanic environments are found at Kallur and Kalmal village which contain numerous round dark spots containing aggregates of olivine and clinopyroxene. Numerous highly coarse pegmatites with huge feldspar crystals cut across all the granite facies. The different facies of plutons are more homogeneous compared to central and southern corridor. Xenoliths are rare whilst rounded to pillow shaped MME are common which rarely show a transition to disrupted synplutonic mafic dyke. These MME are generally medium to fine grained and exhibit magmatic textures similar to their host and also show lobate contact with host pluton. Synplutonic dykes are not common but few fragmented intermediate to mafic dykes are found. North of Gurgunta village a huge spectacular synplutonic mafic dyke traverse the pluton which show various stages of interaction of mafic magmas with crystallizing host pluton involving magma mixing, mingling and hybridization processes (Fig. 26).

\section{Discussion}

Granitoid plutons constitute significant part of preserved continental crust and study of their anatomy and emplacement modes provide useful information on the fundamental architecture, thermal as well as rheological state of continental lithosphere. The emplacement mechanism of plutons is a function of interplay of magma buoyancy and ambient tectonic force. The tectonic control of pluton emplacement is characterized by the study of deformation patterns of plutons and surrounding basement. Globally during the
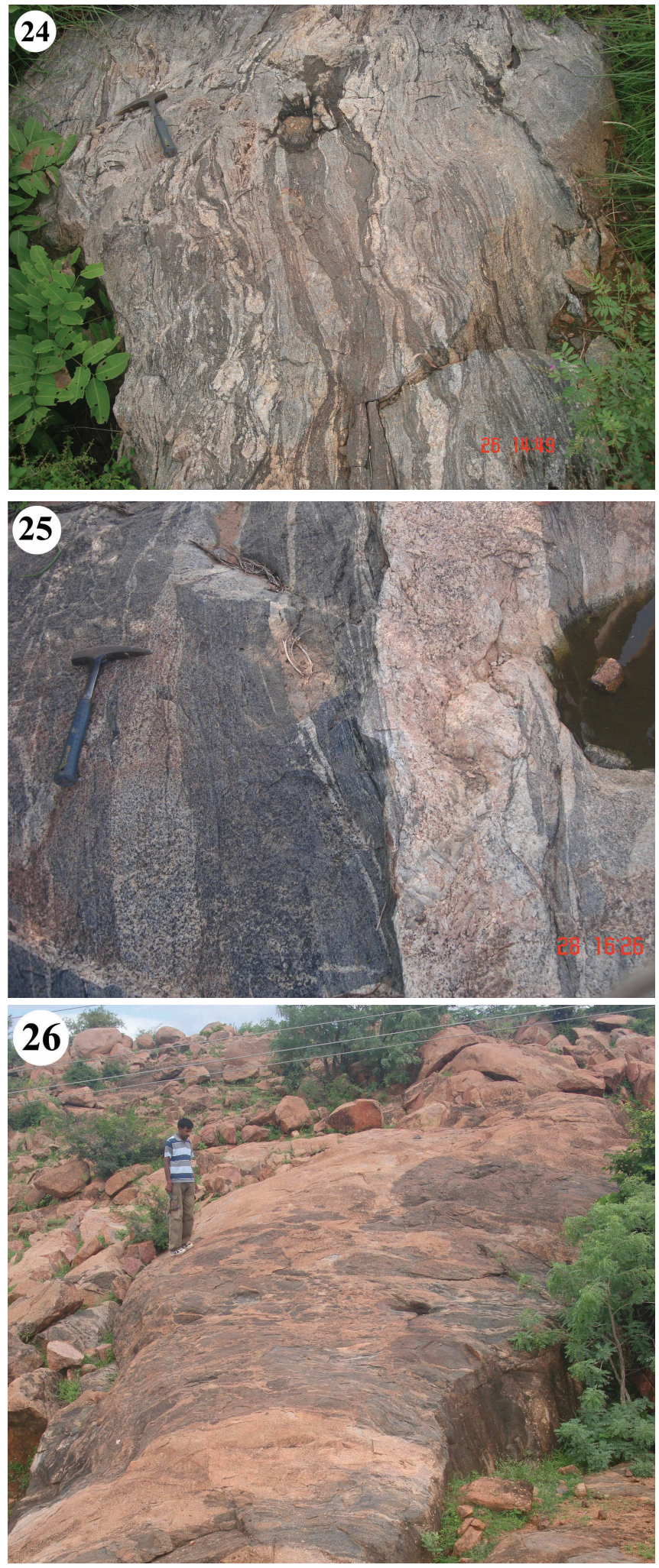

Figures 24-26. 24 - Migmatitic TTG with mafic layers and boudins of leucocratic veins $1 \mathrm{~km}$ before Ganekal in Adoni-Mantralaya road. 25 - Banded tonalitic gneiss with pegmatitic pink vein along foliation at Tippanad cross about $15 \mathrm{~km}$ north of Gangavathi. 26 - View of synplutonic mafic dyke in pink granite showing varying degree of interaction, mixing and mingling at Gollapalli, NW part of Hutti greenstone belt 
last three decades multidisciplinary studies have made an impressive progress in our understanding of granite petrogenesis including pluton emplacement processes, magma chamber dynamics involving interaction of coeval felsic and mafic magmas, thermal rejuvenation of magma chambers (Bonin, 2004; Chardon and Jayananda, 2008; Hutton, 1988; Moyen et al., 2003b). The granitoid plutons covers large part of the EDC and their actual surface area is much more than shown in the published maps. Here we discuss magma chamber processes, spatial link between granitoids magmatism, crustal reworking and regional deformation patterns and tectonic environment of magma generation and emplacement within the regional geological framework of the Dharwar craton.

\section{Anatomy of the plutons at different crustal levels}

The anatomy of plutons and their relationships with surrounding basement reflects the emplacement mechanisms and depth of emplacement in the crust. In the EDC, field data such as contact relationships, strain patterns and documented metamorphic gradient indicate that the exposed plutons correspond to a large crustal panel from lower to upper crust. The volume of plutons progressively increases from deeper to upper crustal levels. The plutons show diffuse contacts in the deepest levels and bounded by $5-10 \mathrm{~km}$ thick migmatite zone whilst contacts becomes relatively sharp in the higher levels reflecting the rheological behavior of the surrounding crust. All the studied plutons contain two major components viz. voluminous intrusive facies and minor anatectic granites (Jayananda et al., 2000).

In the lower crustal levels, plutons are volumetrically minor which are heterogeneous and mixed with basement undergoing partial melting. Abundant diatexites indicate hot ductile nature of the crust. Numerous melt filled ductile shear bands imply a spatial link between shear deformation and lower crustal melting. The mantle derived hot juvenile magmas (monzodiorite, quartz-monzonite and monzogranite) introduced probably as pulses into lower crust which provided heat and fluids required for melting of already hot basement. Numerous disrupted synplutonic mafic dykes in plutons and surrounding diatexites (see Figs. 8 and 9) show that injection of mafic magmas into crystallizing host magmas are contemporaneous with crustal melting leading generation of anatectic granite. The juvenile magmatism and crustal reworking culminated with a major granulite event as attested by incipient granulite overprint on diatexites, intrusive and anatectic facies, and synplutonic mafic dykes.

In the mid-crustal levels plutons becomes voluminous, homogeneous and boundaries become sharper suggesting accumulation of differentiated magmas. A progressive transition from diatexite through inhomogeneous to homogenous granite can be attributed to accumulation and emplacement anatectic magmas. The observed magmatic flow fabrics of anatectic granites and synplutonic mafic bodies (see Fig. 20 and 22) suggest contemporaneous emplacement of anatectic melt and synplutonic mafic dykes. On the other hand solid-state plastic fabrics such as strong alignment as well as stretched feldspar phenocrysts, $\mathrm{C}-\mathrm{S}$ fabrics are common in intrusive facies implying substantial crystallinity in intrusive facies at the time of initiation of shear deformation. Major shear zones confined to periphery of plutons transported numerous basement enclaves, mafic to ultramafic xenoliths from lower crust. The close association of anatectic granite sheets and boudins of intrusive facies with N10$25^{\circ} \mathrm{E}$ trending dextral shear zones suggest regional shear zone development during ascent of anatectic magmas that coincides with cooling of intrusive granitoids (see Fig. 2 and 4). Chadwick et al (2000) and Chardon et al (2008) documented sinistral shear zones with thick mylonites in basement intervening plutons. These N5-14 W trending sinistral shear zones probably developed during the late stage cooling of plutons as they traverse the plutons and contain chlorite-epidote with rotated boudins of intrusive facies. The strong fabrics (often constrictional) in tonalitic gneisses found in between plutonic belts could be related longitudinal constrictional flow of hot orogenic crust during pluton emplacement as documented west of the Closepet granite (Chardon et al., 2011). The most voluminous porphyritic facies often show diffused margins with dark grey quartzmonzonite suggesting their co-magmatic nature. On the other hand, the anatectic facies show cross-cutting relationships with intrusive facies and occasionally show diffuse contacts suggesting short time gap between them. Close to the periphery of the plutons progressive disruption of dark grey quartz-monzonite or dioritic facies with light colored anatectic granite or diatexites during magmatic flow led much of the observed diffuse banding and also biotite schlieren (Fig. 27). Late stage injection of mafic magmas into host plutons caused reversal of crystallization of host leading to back-veining, mingling and hybridization (Fig. 28).

Plutons in the upper crustal levels form homogeneous intrusions with occasional enclaves and synplutonic mafic rocks. In northern
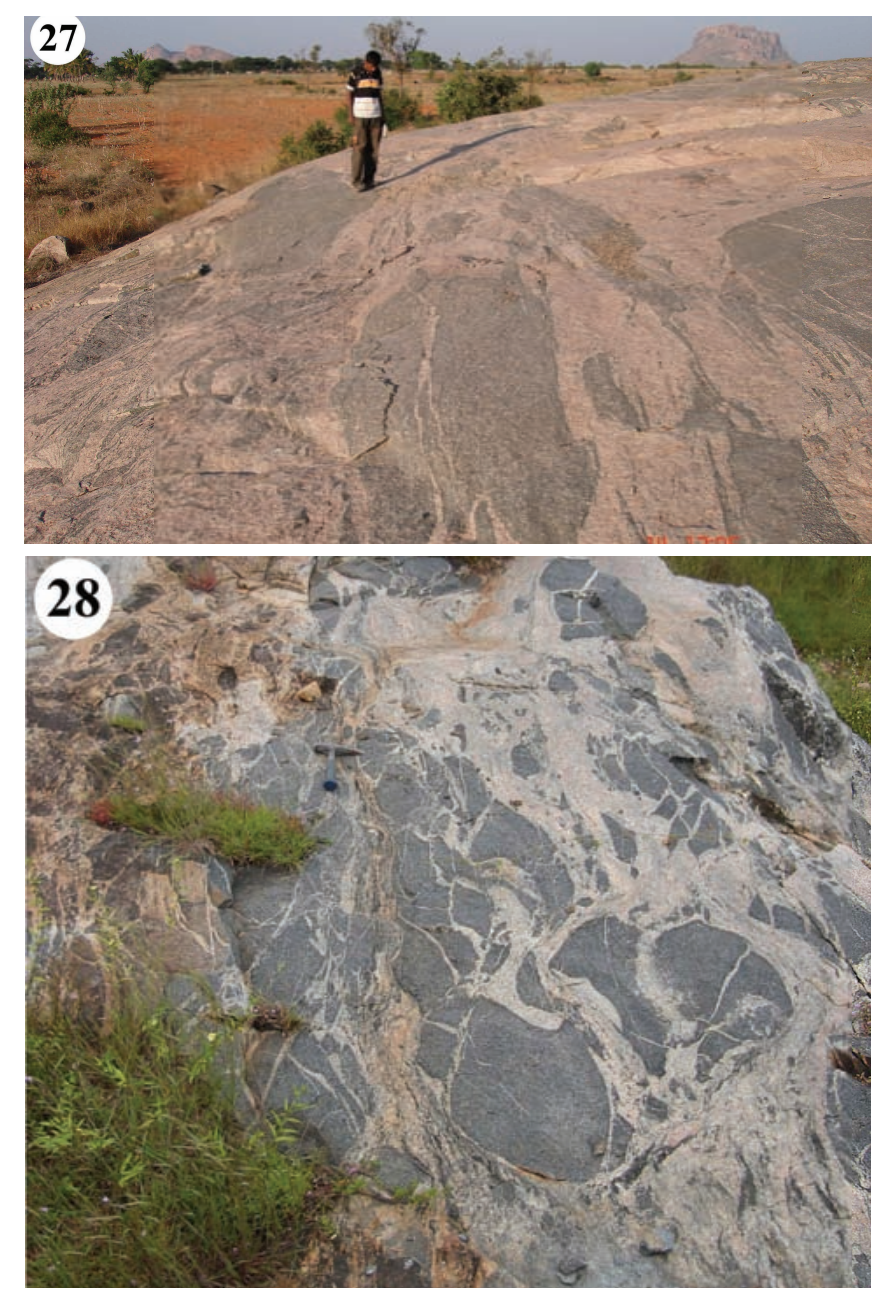

Figure 27 - Anatectic granite with disrupted quartz-monzonite define diffusive banding at $6 \mathrm{~km}$ from Pavagada in Sira road. 28 Back-veining of leucocratic veins in disrupted synplutonic mafic dyke $32 \mathrm{~km}$ west of Bangalore in Magadi road. 
part of EDC, occurrence of diorite (extremely fine grained rocks with plagioclase and clinopyroxene crystals) intrusions in sub-volcanic environments imply shallow crustal levels. Trains of dismantled synplutonic mafic dykes in pink granites and also dark grey dioritic to quartz-monzonite facies co-mingled with light grey facies also suggest coeval felsic and mafic magmas in sub-volcanic environment. The plutons show intrusive relationships with greenstone belts (HuttiMuski, Deodurg and Hungund) but on an outcrop scale pink or light grey veins are found along foliation of amphibolites.

\section{Magma chamber processes (Magma Chamber processes, coevalfelsic and mafic magmas, mixing and hybridization)}

Interaction of felsic and mafic magmas with mixing or mingling and progressive hybridization processes have been widely documented from plutons in the arc environments of Phanerozoic plate margin settings (Bateman, 1995; Barnes et al., 2002; Foster and Hyndman, 1990; Frost and Mahood, 1987; Reid and Hamilton, 1987; Santosh Kumar, 2010; Turnbull et al., 2010). The interaction of mafic injections with host felsic magmas is poorly known in the Archaean granitoid plutons as they are often affected by deformation and metamorphism. Although several studies focused on the structure and emplacement of late Archaean granitoid plutons in the EDC (Chadwick et al., 2000; Chardon and Jayananda, 2008; Moyen et al., 2003a), magma chamber processes particularly coeval felsic and mafic magmas, mixing, mingling and hybridization processes is poorly documented (Jayananda et al., 2009; Prabhakar et al., 2009a).

In the EDC the plutons exhibit field evidences for magma chamber processes particularly for coeval mafic and host felsic magmas, their interaction, mixing, mingling and hybridization processes. A number of features such as cuspate contacts between mafic injections and felsic host, similar magmatic fabrics and presence of large k-feldspar phenocrysts with rapakivi/orbicular textures (Fig. 29) and dismembered synplutonic mafic dykes indicate coeval nature of felsic and mafic magmas. Figuress 30a-c shows demonstrate for coeval mafic and felsic magmas in all the three studied corridors corresponding to different crustal levels in EDC. The presence of several rounded to pillowed mafic enclaves and dismembered synplutonic mafic dykes with chilled margins also indicate injection

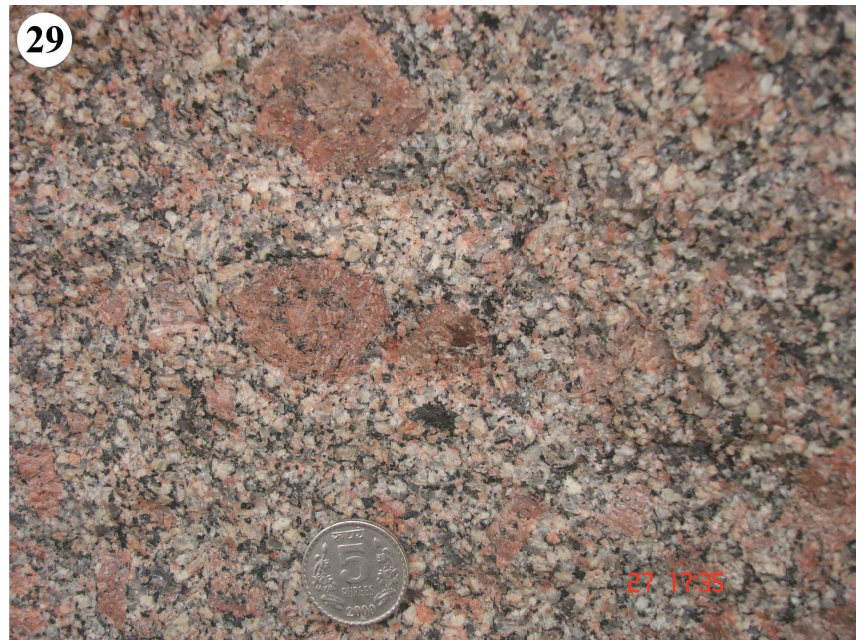

Figure 29. K-feldspar phenocryst showing crude orbicular texture, $\sim 3 \mathrm{~km}$ north of Gurganta.
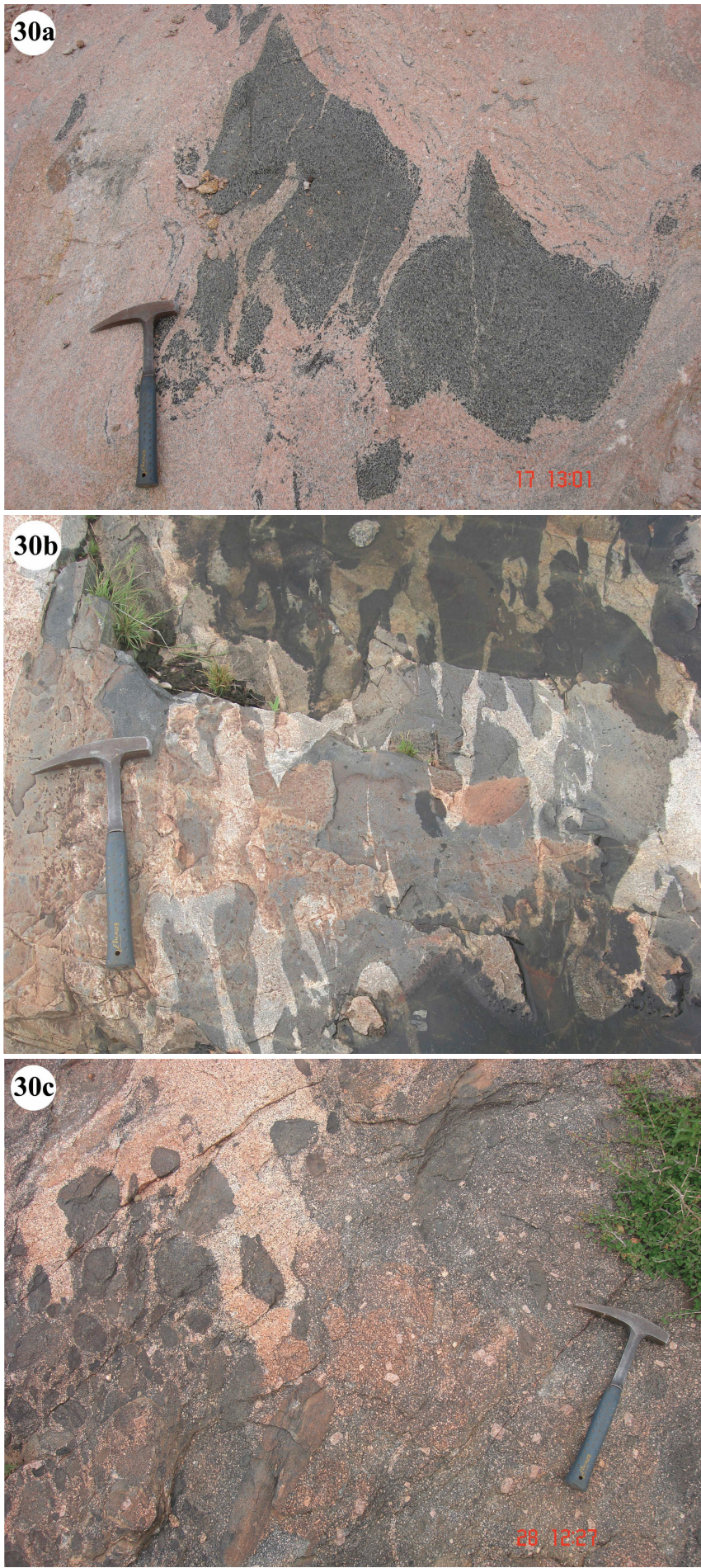

Figure 30. (a) Boudins of synplutonic dyke showing interaction with felsic host $\sim 8 \mathrm{~km}$ east of Kabbaldurga. (b) Exposure showing magma mingling process $\sim 10 \mathrm{~km}$ from Penukonda in Madakasira road. (c) Exposure showing mixing, mingling and hybridization process at $~ 3 \mathrm{~km}$ north of Gurgunta in Gulbarga road.

of mafic magmas into crystallizing host magma. The mafic magmas appears to be entered into crust at the time anatectic melts begin to move upwards as revealed by magmatic flow structures defined by mafic magmas and anatectic melts. The synplutonic mafic dykes are generally disrupted but occasionally continuous implying their injection into host felsic magma with different crystallinity. They 
display sharp to crenulated contacts with the felsic host indicating solidified margins and liquidus interiors (see Fig. 30b). Interaction, mixing of coeval mafic and felsic host leading to hybridization can be observed in several stages. Injection of mafic magma into felsic crystallizing host or anatectic zone cause thermal disequilibrium as mafic magma cause local increase in temperature thus melt content may further increased in felsic host. The heat and volatiles of the mafic magma also cause reversal of crystallization of felsic host causing local interaction and back veining.

\section{Spatial link between 2.7-2.5 Ga juvenile magmatism, crustal reworking and regional deformation patterns}

Geochronologic and Nd isotopic data reveal that EDC was built in two major episodes of crust accretion during 2.7-2.65 Ga and 2.572.52 Ga (Jayananda et al., 2012) with large 3.35-3.0 Ga remnants of old crust found in the western boundary of the Closepet granite (Chardon et al., 2011; Friend and Nutman, 1991; Mahabaleswar et al., 1995). The 2.7-2.65 Ga crust accreted in the form of mafic greenstone volcanism and tonalitic to granodioritic plutonism contributing to large scale continental growth (Balakrishnan et al., 1990, 1999; Anand and Balakrishnan, 2010; Jayananda et al., 2012). This major episode of crust accretion outlasted with the reworking of ancient crust and granulite metamorphism close to UHT conditions and emplacement of potassic plutons along western fringe of EDC close to $2.62 \mathrm{Ga}$ (Jayananda et al., 2006, 2011). The 2.57-2.52 Ga corresponds to period of intense geological activity in the EDC. During this period large quantities of juvenile magmatic materials accreted to the EDC (Krogstad et al., 1991, 1995; Jayananda et al., 2000, 2012; Peucat et al., 1993b; Dey et al., 2012). Besides the Closepet granite, all other north-south trending magmatic intrusion in the east (see Fig.1) emplaced during this event. More recently Jayananda et al (2009) document widespread occurrence of MME and synplutonic mafic dykes in 2.57-2.52 Ga plutons. This juvenile magmatic accretion spatially associated with the reworking of ancient crust as revealed by field data and $\mathrm{U}-\mathrm{Pb}$ zircon ages of $2.57-2.53 \mathrm{Ga}$ intrusive and 2.53 -2.52 Ga anatectic facies (Friend and Nutman, 1992; Jayananda et al., 1995, 2000). Innumerable synplutonic mafic dykes traverse the host crystallizing granitoids probably supplied additional heat and volatiles for crustal reworking. These hot mafic magmas show interactions, mixing and mingling with crystallizing host granitoid magmas. The 2.57-2.52 Ga accretion culminated with granulite to greenschist facies regional metamorphism at $2.5 \mathrm{Ga}$ that affected whole Archaean crust which followed slow cooling and final cratonization close to $2.45 \mathrm{Ga}$ (Jayananda et al., 2000). The above lines of arguments suggest that the two major episodes of accretion (2.7-2.65 Ga and $2.57-2.5 \mathrm{Ga}$ ) contributed to the large scale continental growth in the EDC which are spatially associated with reworking and cratonization at the end of Archaean.

\section{Tectonic context of magma generation and emplacement}

Any model proposed on the Neoarchean evolution of EDC should explain the observed bimodal age distribution of greenstone sequences and TTG - granitoids of 2.7-2.65 and 2.57-2.52 Ga. More recently based on elemental characteristics of EDC greenstone sequences, Manikyamba and Kerrich (2012) proposed a two stage accretion of
2.7-2.65 Ga continental lithosphere in EDC wherein komatiite and high-Mg basalts attributed to plume melting whilst associated tholeiite to calc-alkaline basalts explained by subduction of young hot oceanic lithosphere. On the other hand Jayananda et al (2012) explained 2.7-2.67 Ga mafic greenstone volcanism and surrounding TTG by a combined plume-arc setting. In this model melting of plume below oceanic lithosphere generate $\mathrm{Mg}$-rich mafic magmas forming oceanic plateaus and shallow angle subduction of intervening hot oceanic crust generated TTG magmas. In the present contribution we briefly discuss about 2.57-2.52 Ga magmatic accretion and associated crustal reworking and high-T and low-P regional metamorphism. Based on our field data from three corridors in EDC together with published ages and Nd-Sr isotopic data, and metamorphic P-T paths we discuss a combined model involving lateral accretion in arc setting for generation of granitoid magmas followed by a plume impact to account reworking, granulite metamorphism and cratonization. Field observations in the three studied corridors show emplacement of huge quantities of granitoid magmas with subordinate coeval mafic magma injections. Published age data (Jayananda et al., 2012 and references therein) together with our unpublished ages show that granitoid magmas (intrusive and anatectic) and mafic injections are coeval emplaced during 2.57-2.52 Ga. Nd-Sr isotope data reveal major juvenile source for granitoids with minor crustal input. Consequently the granitoid magmas must be derived either by direct melting of mantle or melting of down going oceanic slab in arc setting. In this study with the field data alone we are unable to constrain role of mantle and slab in granitoid magma generation. However, several recent studies (e.g. Martin et al., 2010; Moyen et al., 2010) show that decrease in geothermal gradients during the end of Archaean, smaller degree of slab melting occurred at greater depths. In such conditions the slab melts strongly contaminated with overlying mantle during their passage to crust. The proposed model involves westward subduction oceanic slab and melting of down going slab at greater depth $(50-60 \mathrm{~km})$ generated felsic to intermediate magmas. The resultant magmas rise through thick column of overlying mantle causing interaction of slab melts with the mantle gaining compatible elements (Moyen et al., 2003b). Accumulation and differentiation of calc-alkaline magmas in the deep crust leads to development of shrinkage cracks to the mantle depth causing the decompression melting of mantle. The resultant mafic magmas injected into crystallizing magma chambers in the crust where they show varying degree of interaction with the host depending on the crystallinity. The heat and fluids associated with slab derived magmas cause partial melting of surrounding TTG crust resulting in anatectic melts. Closure of arcs during ca. $2.52 \mathrm{Ga}$ and catastrophic collapse of down-going slabs at $660 \mathrm{~km}$ depth triggered plume production (Condie, 1998) which rise below continental crust causing the reworking of old as well as newly formed juvenile crust and regional metamorphism. Such mechanisms explain the observed field, petrological characteristics of the composite granitoids plutons including synplutonic mafic dykes, reworking, $2.5 \mathrm{Ga}$ hot metamorphism and final cratonization of Archaean crust with slow cooling rates upto $2.4 \mathrm{Ga}$ (Jayananda and Peucat, 1996; Peucat et al., 1993b).

\section{Conclusions}

The conclusions of the present study can be summarized as follows:

1. The late Archaean granitoid plutons in the EDC are composite 
containing dominant intrusive as well as minor anatectic facies and form windows to magma chamber processes at different crustal levels

2. The granitoid plutons contain significant amount of coeval magmas represented by MME and synplutonic mafic dykes.

3. Mafic magmas inject into crystallizing host with varying degree of crystallinity and show different stages of interaction, mixing, mingling and hybridization

4. Field data show $2.57-2.52$ Ga magmatism is spatially associated with crustal reworking, regional metamorphism and cratonization of Archaean crust and

5. 2.57-2.5 Ga magmatism and reworking processes can be attributed to two stage model involving slab melting in arc setting followed by a plume impact.

\section{Acknowledgements}

This work was funded by Department of Science and Technology (DST), Govt. of India funded project ESS/16/297/2007. T. Hokada, Y.J.Bhaskar Rao and Santosh Kumar provided constructive reviews. Dr. Ch Sivaji and Dr. Manoranjan Mohanty of DST are thanked for efficient administrative support. M.J gratefully acknowledges T.Kano and T. Miyazaki for fruitful discussions. Kowete-ü Sekhamo is financially supported by CSIR Fellowship.

\section{References}

Anand, R., and Balakrishnan, S., 2010, Pb, Sr and Nd isotope systematics of metavolcanic rocks of the Hutti greenstone belt, Eastern Dharwar craton: Constraints on age, duration of volcanism and evolution of mantle sources during Late Archaean. Journal of Asian Earth Sciences, v. 39, pp. 1-11.

Anil Kumar, Bhaskar Rao, Y.J., Sivaraman, T.V., and Gopalan, K., 1996, Sm-Nd ages of Archaean metavolcanics of the Dharwar craton, south India. Precambrian Research, v. 80, pp. 205-216.

Balakrishnan, S., Hanson, G.N. and Rajamani, V., 1990, Pb and Nd isotope constrains on the origin of high $\mathrm{Mg}$ and tholeiitic amphibolites, Kolar Schist Belt, South India. Contribution to Mineralogy Petrology, v. 107, pp. 279-292.

Balakrishnan, S., Rajamani, V., and Hanson, G. N., 1999, U-Pb ages for zircon and titanite from the Ramagiri area, Southern India: evidence for accretionary origin of the eastern Dharwar Craton during the late Archaean. Journal of Geology, v. 107, pp. 69-86.

Barbarin, B., 1999, A review of the relationships between granitoid types, their origins and their geodynamic environments. Lithos, v. 46, pp. 605626

Barbarin, B., 2005, Mafic magmatic enclaves and mafic rocks associated with some granitoids of the Central Sierra Nevada batholiths, California: nature, origin, and relations with the hosts. Lithos, v. 80, pp. 155-177.

Barnes, C. G., Yoshinobu, A. S., Prestvik, T., Nordgulen, O., Karlsson, H. R. and Sundvoll, B., 2002, Mafic magma intraplating: Anatexis and hybridization in arc crust, Bindal batholiths, Norway. Journal of Petrolology, pp. 2171-2190.

Bateman, R., 1995, The interplay between crystallization, replenishment and hybridization in large felsic magma chambers. Earth Science Review, v. 39, pp.91-106.

Bhaskar Rao, Y.J., Anil Kumar, Vrevsky, A.B., Srinivasan, R., Anantha Iyer, G.V., 2000. Sm-Nd ages of two meta-anorthosite complexes around Holenarsipur: Constraints on the antiquity of Archaean supracrustal rocks of the Dharwar craton. Proceedings Indian Academy of Science (Earth Planetary Science) 109, 57-65.

Bhaskar Rao, Y. J., Sivaraman, T. V., Pantulu, C. V. C., Gopalan, K. and Naqvi, S. M., 1992, Ages of late Archaean metavolcanics and granites,
Dharwar craton: Evidence for early Proterozoic thermo-tectonic events. Precambrian Research, v. 38, pp. 246-270.

Bhaskar Rao, Y.J., Griffin, W.L., Ketchum, J., Pearson, N.J., Beyer, E., and O'Reilly, S.Y., 2008, An outline of juvenile crust formation and recycling history in the Archaean Western Dharwar craton, from zircon in situ U$\mathrm{Pb}$ dating and Hf-isotopic compositions. Abstract, Goldschmidt Conference 2008, Geochimica Cosmochimica Acta 72, A81.

Bonin, B. 2004, Do coeval mafic and felsic magmas in post-collisional to within-plate regimes necessarily imply two contrasting, mantle and crustal, sources? A review. Lithos, v. 78, pp 1-24.

Bouhallier, H., Choukroune, P., and Ballèvre, M., 1993, Diapirisam, bulk homogeneous shortening and transcurrent shearing in the Archaean Dharwar craton: the Holenarsipur area, Southern India. Precambrian Research, v. 63, pp. 43-58.

Bouhallier, H., 1995, Evolution structurae et metamorphic de la croute continentale archeenne (cratin de Dharwar Inde du sud) in: Mem. Doc., Geoscienes Rennes v. 60, pp. 214.

Brun, J.-P., 1983, Isotropic points and lines in strain fields, Journal of Structural Geology, v. 5, pp. 321-327.

Castro, A., 1987, Structural pattern and ascent model in the Central Extremadura batholith, Hercynian belt, Spain: Reply. Journal of Structural Geology, v. 9 (3), pp. 383-384.

Chadwick, B., Vasudev, V.N. and Hegde, G.V., 1999, Magmatism, structure, Emplacement and Plate Tectonic setting of the Late Archaean Dharwar Batholith in North East Karnataka and South West Andhra Pradesh. Department of Mines and Geology, Government of Karnataka, Geological Studies No. 316.

Chadwick, B., Vasudev, V. N. and G. V. Hedge., 2000, The Dharwar craton, southern India, interpreted as the result of Late Archaean oblique convergence, Precambrian Research, v. 99, pp. 91-101.

Chadwick, B., Vasudev, V.N., Hegde, G.V. and Nutman, A.P., 2007, Structure and SHRIMP U/Pb zircon ages of granites adjacent to the Chitradurga schist belt: Implications for Neoarchaean convergence in the Dharwar craton, southern India. Journal Geological Society of India, v. 69, pp. 524.

Chardon, D., Choukroune, P. and Jayananda, M., 1996, Strain patterns, décollement and incipient sagducted greenstone terrains in the Archaean Dharwar craton (South India). Journal of Structural Geology, v. 18, pp. 991-1004.

Chardon, D., Choukroune, P., and Jayananda, M., 1998, Sinking of the Dharwar basin (South India): implications for Archaean tectonics. Precambrian Research, v. 9, pp. 15-39.

Chardon, D., Peucat, J.-J., Jayananda, M., Choukroune, P., and Fanning, C. M., 2002, Archaean granite-greenstone tectonics at Kolar (South India): interplay of diapirism and bulk inhomogeneous contraction during magmatic juvenile accretion, Tectonics, v. 21, pp. 10-16.1029/ 2001 TC901032.

Chardon, D., Jayananda, M., Chetty, T.R.K. and Peucat, J-J., 2008, Precambrian continental strain and shear zone patterns: the South Indian case. Journal of Geophysical Research, v.113, B08402, doi: 10.1029/ 2007JB005299.

Chardon, D., and Jayananda, M., 2008, Three dimensional field perspective on deformation, flow, and growth of the lower continental crust (Dharwar craton, India), Tectonics, v. 27, TC1014, doi: 10.1029/2007TC002120.

Chardon, D., Jayananda, M. and Peucat, J. J., 2011, Lateral constrictional flow of hot orogenic crust: Insights from the Neoarchaean of south India, geological and geophysical implications for orogenic plateaux. v. 12 (2), Q02005, doi: 10.1029/2010GC003398, ISSN: 1525/2027

Choukroune, P., Bouhallier, H. and Arndt, N.T., 1994, Soft lithosphere during periods of Archaean crustal growth or crustal reworking. In: Coward, M.P. and Riess, A.C. (eds.) Early Precambrian Processes. Geological Society of London, Special Publication, v. 95, pp. 67-86.

Chown, E.H., Harrap, R., and Abdelali Moukhsil., 2002, The role of granitic intrusions in the evolution of the Abitibi belt, Canada. Precambrian Research, v. 115, pp. 291-310.

Condie, K.C., 1998, Episodic continental growth and supercontinents: a 
mantle avalanche connection? Earth and Planetary Science Letters, v. 163 , pp. 97-108.

Cruden, A. R. and Launeau, P., 1994, Structure, magnetic fabric and emplacement of the Archaean Lebel Stock, SW Atibiti Greenstone Belt. Journal of Structural Geology, v. 16, pp. 677-691.

Dey, S., Pandey, U.K., Rai, A.K., Chaki, A., 2012. Geochemical and Nd isotope constraints on petrogenesis of granitoids from NW part of the eastern Dharwar craton: Possible implications for late Archaean crustal accretion. Journal of Asian Earth Sciences, v. 45, pp. 40-56.

Drury, S.A., 1983, A regional tectonic study of the Archaean Chitradurga greenstone belt, Karnataka, based on LANDSAT interpretation. Journal Geological Society of India, v. 24, pp. 167-184.

Foster, D.A. and Hyndman, D.W. 1990, Magma mixing and mingling between synplutonic mafic dykes and granite in the Idaho-Bitterroot batholith. in: J.L. Anderson (Ed.), The nature and origin of Cordilleran Magmatism, Geological Society of America, Memoir 174, pp. 347-358.

Friend, C. R. L., and A. P. Nutman., 1991, SHRIMP U-Pb geochronology of the Closepet granite and Peninsular gneisses, Karnataka, South of India, Journal Geological Society of India, v. 38, pp. 357-368.

Friend, C.R.L. and Nutman, A.P., 1992, Response of U-Pb isotopes and whole rock geochemistry to $\mathrm{CO}_{2}$ induced granulite metamorphism, Kabbaldurga, Karnataka south India. Contribution to Mineralogy and Petrology, v. 111, pp. 299-310.

Frost, T. P and Mahood, G. A., 1987, Field, chemical, and physical constraints on mafic-felsic magma interaction in the Lamarck Granodiorite, Sierra Nevada, California. Geological Society of America Bulletin, v. 99, pp. 272-291.

Halla Jaana., 2005, Late Archaean high-Mg granitoids (sanukitoids) in the southern Karelian domain, eastern Finland: $\mathrm{Pb}$ and $\mathrm{Nd}$ isotopic constraints on crust-mantle interactions. Lithos, v. 79, pp. 161-178.

Harish Kumar, S.B., Jayananda, M., Kano, T., Shadakshara Swamy, N., and Mahabaleshwar, B., 2003, Late Archaean Juvenile magmatic accretion process in the Eastern Dharwar craton: Kuppam Karimangalam area. Memoir Geological Society of India., no. 50, pp. 375-408.

Heilimo, E., Halla, J., Hölttä, P., 2010, Discrimination and origin of the sanukitoid series: Geochemical constraints from the Neoarchaean western Karelian Province (Finland). Lithos, v. 115, pp. 27-39.

Hutton, D. H. W., 1988, Granite emplacement mechanisms and tectonic controls: inferences from deformation studies, Transactions of the Royal Society of Edinburgh: Earth sciences, v. 79, pp. 245-255.

Janardhan, A. S., R. C. Newton, and E. C. Hansen., 1982, The transformation of amphibolite facies gneisses to charnockite in southern Karnataka and Tamil Nadu, Contribution to Mineralogy Petrolology, v. 79, pp. 139149.

Jayananda, M and Peucat, J-J., 1996. Geochronologic framework of southern India. Gondwana Research Memoir 3, Field Science Publishers (Osaka) pp. 53-75.

Jayananda, M., H. Martin, J.-J. Peucat, and B. Mahabaleswar., 1995, Late Archaean crust-mantle interactions: geochemistry of LREEenriched mantle derived magmas. Example of the Closepet batholith, Southern India, Contribution to Mineralogy and Petrology, v. 119, pp. 314-329.

Jayananda, M., Moyen, J.-F., Martin, H., Peucat, J.-J., Auvray, B., and Mahabalesawar, B., 2000, Late Archaean (2550-2520 Ma) juvenile magmatism in the Eastern Dharwar craton, southern India: constraints from geochronology, $\mathrm{Nd}-\mathrm{Sr}$ isotopes and whole rock geochemistry. Precambrian Research, v. 99, pp. 225-254.

Jayananda, M., Chardon, D., Peucat, J-J., Capdevila, R., 2006, 2.61 Ga potassic granites and crustal reworking in the western Dharwar craton, southern India:tectonic, geochronologic and geochemical constraints. Precambrian Research, v. 150, pp. 1-26.

Jayananda, M., T. Kano, J. J. Peucat, and S. Channabasappa., 2008, 3.35 Ga komatiite volcanism in the western Dharwar craton, southern India: Constraints from Nd isotopes and whole rock geochemistry, Precambrian Research, v. 162, pp. 160-179.

Jayananda, M., Miyazaki, T., Gireesh, R.V., Mahesha, N. and Kano, T., 2009, Synplutonic mafic dykes from late Archaean granitoids in the Eastern Dharwar Craton, Southern India. Journal of Geological Society of India, v. 73 , pp. $117-130$.
Jayananda, M., Banerjee, M., Pant, N. C., Dasgupta, S., Kano, T., Mahesha, N. and Mahableswar, B., 2011, 2.62 Ga high temperature metamorphism in the central part of the Eastern Dharwar Craton: implications for late Archaean tectonothermal history. Geological Journal. DOI: 10.1002/ gj.1308.

Jayananda, M., Peucat, J.-J., Chardon, D., Krishna Rao, B., Fanning, C.M., and Corfu, F., 2012, Neoarchaean greenstone volcanism and continental growth, Dharwar craton, south India. Constraints from SIMS U-Pb zircon geochronology and Nd isotopes. Precambrian Research, 10.1016/ j.precamres.2012.05.002.

Krogstad, E.J., Balakrishnan, S., Mukhopadhyay, D.K., Rajamani, V. and Hanson, G.N., 1989, Plate tectonics at 2.5 by ago: evidence from Kolar schist belt, south India. Science, v. 243, pp. 1337-1340.

Krogstad, E.J,. Hanson, G.N. and Rajamani, V., 1991, U-Pb ages of zircon and sphene for two gneiss terranes adjacent to the Kolar Schist Belt, South India: evidence for separate crustal evolution histories. Journal of Geology, v. 99, pp. 801-816.

Krogstad, E.J,. Hanson, G.N. and Rajamani, V., 1995, Sources of continental magmatism adjacent to the late Archaean Kolar Suture zone, South India: Distinct isotopic and elemental signature of two late Archaean magmatic series. Contribution to Mineralogy and Petrology, v. 122, pp. 159-173.

Mahabaleshwar, B. Shadakshrara Swamy, N. and Jayananda, M., 1995, Geochemistry of metapelites from Archaean high terrain of southern Karnataka, South India. In: M. Yoshida and M. Santosh (Eds.), India and Antartica during Precambrian. Memior of Geological Society of India, no. 34, pp. 259-271.

Manikyamba, C and Kerrich, R. 2012, Eastern Dharwar craton, India: Continental lithosphere growth by diverse plume and arc terranes. Geoscience Frontiers, v. 3, pp. 225-240.

Manikyamba, C., Kerrich, R., Tarun C. Khanna, Satyanarayanan, M., and Keshav Krishna., 2009, Enriched and depleted arc basalts, with Mgandesites and adakites: A potential paired arc-back-arc of the $2.6 \mathrm{Ga}$ Hutti greenstone terrane, India. Geochimica et Cosmochimica Acta, v. 73, pp. 1711-1736.

Martin, H., Smithies R.H., Rapp R. Moyen J.-F., and Champion D., 2005. An overview of adakite, tonalite-trondhjemite-granodiorite (TTG), and sanukitoid: relationships and some implications for crustal evolution. Lithos, v. 79, pp. 1-24.

Martin, H., Moyen, J-F and Rapp, R. 2010, The sanukitoid series: magmatism at the Archaean-Proterozoic transition Transactions of the Royal Society of Edinburgh, v. 100, pp. 15-33.

Meen, J.K., Rogers, J.J., Fullagar, P.D., 1992, Lead isotopic composition of the western Dharwar craton, southern India: evidence for distinct middle Archaean terrenes in a late Archaean craton. Geochimica et Cosmochimica Acta, v. 56, pp. 2455-2470.

Mojzis, S. J., T. C. Devaraju, and R. C. Newton ., 2003, Ion microprobe U-Pb age determinations on zircon from the late Archaean granulite facies transition zone of southern India, Journal of Geology, v. 111, pp. 407425 .

Moyen, J.-F., A. Nédélec, H. Martin, and M. Jayananda., 2003a, Syntectonic granite emplacement at different structural levels: the Closepet granite, South India, Journal of Structural Geology, v. 25, pp. 611-631.

Moyen, J.-F., Martin, A., Jayananda, M. and Auvray, B., 2003b, Late Archaean granites: a typology based on the Dharwar craton (India). Precambrian Research, v. 127, pp. 102-123.

Moyen, J.-F., H. Martin, and M. Jayananda., 2001, Multi-element geochemical modelling of crust-mantle interactions during late Archaean crustal growth: the Closepet granite (South India), Precambrian Research, v. 112, pp. 87-105.

Moyen J.-F., Champion, D and Smithies R.H., 2010, The geochemistry of Archaean plagioclase-rich granites as a marker of source enrichment and depth of melting. Transactions of the Royal Society of Edinburgh, v. 100 , pp. $35-50$.

Naqvi, S.M., Khan, R.M.K., Manikyamba, C., Ram Mohan, M. and Khanna, T.C., 2006, Geochemistry of the Neoarchaean high-Mg basalt, boninites and adakites from the Kushtagi- Hungund greenstone belt of the Eastern Dharwar craton (EDC); implications for the tectonic setting: Journal Asian Earth Science, v. 27, pp. 25-44.

Neves, S. P. and Vauchez, A., 1995, Successive mixing and mingling of magma 
in a plutonic complex of northeast Brazil. Lithos, v. 34, pp. 275-299.

Nutman, A.P., Chadwick, B., Krishna Rao, B. and Vasudev, V.N., 1996, SHRIMP U/Pb zircon ages of acid volcanic rocks in the Chitradurga and Sandur groups, and granites adjacent to the Sandur Schist belt, Karnataka. Journal of Geological Society of India, v. 47, pp. 153-164.

Nutman, A.P., Chadwick, B., Ramakrishnan, M. and Viswanatha, M.N., 1992, SHRIMP U-Pb ages of detrital zircon in Sargur supracrustal rocks in western Karnataka, southern India. Journal of Geological Society of India, v. 39, pp. 367-374.

Paterson, S. R., Fowler Jr, T. K, Miller, R. B., 1996, Pluton emplacement in arcs: a crustal - scale exchange process. Transactions of the Royal Society of Edinburgh, Earth Sciences, v. 87, pp. 115-124.

Paterson, S. R., Pignotta, G. S., Vernon, R. H., 2004, The significance of microgranitoid enclave shapes and orientations. Journal of Structural Geology, v. 26, pp. 1465-1481.

Peucat, J-J., Mahabaleswar, B. and Jayananda, M., 1993a, Age of younger tonalitic magmatism and granulite metamorphism in the Amphibolitegranulite transition zone of Krishnagiri area and comparison with the older gneisses from Gorur-Hassan area. Journal of Metamorphic Geology, v. 11 , pp. 879-888.

Peucat, J.J., Gruau, G., Martin, H., Aurvay, B., Fourcade, S., Choukroune, P., Bouhallier, H., Jayananda, M., 1993b, A 2.5 Ga Mega-Plume in southern India? Terra Nova, v. 97, pp. 321.

Peucat, J-J., Bouhallier, H., Fanning, C.M. and Jayananda, M., 1995, Age of Holenarsipur schist belt, relationships with the surrounding gneisses (Karnataka, south India). Journal of Geology, v. 103, pp. 701-710.

Prabhakar, B.C., Jayananda, M., Mohamed Shareef and Kano, T. 2009a, Synplutonic mafic injections into crystallizing granite pluton from Gurgunta area, northern part of Eastern Dharwar craton: implications for magma chamber processes. Journal of Geological Society of India, v. 74, pp. 177-188.

Prabhakar, B.C., Jayananda, M., Mohamed Shareef and Kano, T., 2009b, Petrology and geochemistry of late Archaean granitoids in the northern part of eastern Dharwar craton, Southern India: Implications for transitional geodynamic setting. Journal of Geological Society of India, v. 74, pp. 299-319.

Ramsay, J.G., 1989, Emplacement kinematics of a granite diapir: the Chindamora batholith, Zimbabwe. Journal of Structural Geology, v. 11, pp. 191-209.

Reid, J.B. Jr., and Hamilton, M. A., 1987, Origin of the Sierra Nevada granite: evidence from small scale composite dikes. Contribution to Mineralogy and Petrology, v. 96, pp. 441--454.

Rogers, A.J., Kolb, J., Meyer, F.M., and Armstrong R.A., 2007, Tectonomagmatic evolution of the Hutti-Maski Greenstone Belt, India: Constrained using geochemical and geochronological data. Journal of Asian Earth Science, v.31, pp. 55-70.

Santosh Kumar., 2010, Mafic to hybrid microgranular enclaves in the Ladakh batholith, northwest Himalaya: Implications on calc-alkaline magma chamber processes, Journal of Geological Society of India, v.76, pp. 525.

Sarvothaman, H., 2001, Archaean high-Mg granitoids of mantle origin in the eastern Dharwar craton of Andhra Pradesh. Journal of Geological Society of India, v. 58, pp. 261-268.

Swami Nath, J., Ramakrishnan, M. and Viswanatha, M.N., 1976, Dharwar stratigraphic model and Karnataka craton evolution. Geological Survey of India Records, v. 107, pp. 149-175.

Sylvester, P.J., 1994. Archaean granite plutons. In: Condie, K. (Ed.), Archaean Crustal Evolution. Developments in Precambrian Geology. Elsevier, Amsterdam, pp. 261-314.

Tobisch, O. T., McNulty, b. a., Vernon, R. H., 1997, Microgranitoid enclave swarms in granitic plutons, central Sierra Nevada, California. Lithos, v. 40, pp. 321-339.

Trendall, A.F., DE Laeter, J.R., Nelson, D.R., Mukhopadhyay, D. 1997a, A precise $\mathrm{U}-\mathrm{Pb}$ age for the base of Mulaingiri formation (Bababudan Group, Dharwar Supergroup) of the Karnataka craton. Journal of Geological Society of India,, v.50, pp.161-170.

Turnbull, R., Weaver, S., Tulloch, A., Cole, J., Handler, M., and Ireland, T., 2010, Field and Geochemical Constraints on mafic-felsic interactions, and processes in high-level arc magma chambers: an example from the Halfmoon pluton, New Zealand. Journal of Petrology, v. 51, pp. $1477-$ 1505.

Vasudev, V.N., Chadwick, B., Nutman, A.P., and Hegde, G.V., 2000, Rapid development of late Archaean Hutti schist belt, northern Karnataka: implications of new field data and SHRIMP zircon ages. Journal of Geological Society of India, v. 55, pp. 529-540.

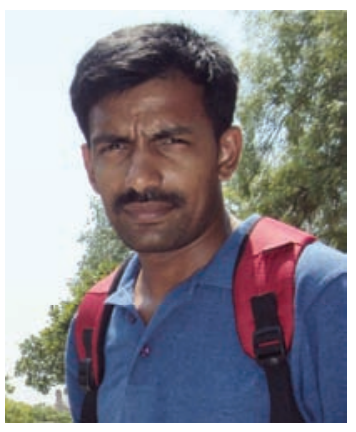

R.V. Gireesh obtained his Masters degree from University of Mysore. He has worked on synplutonic mafic dykes from Neoarchean granitoid plutons in the Eastern Dharwar Craton, Southern India for his PhD thesis to characterize magma chamber processes particularly interaction of coeval felsic and mafic magmas. His current research interests are magmatism in different tectonic settings, spatial link between magmatism and mineralization.

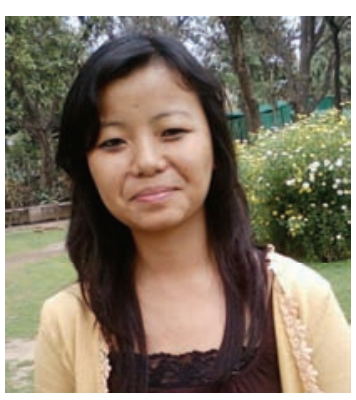

Kowete-ü Sekhamo has finished her M.Sc degree from Bangalore University in 2008. Currently she is a doctoral student at University of Delhi working on crustal accretion patterns and continental growth in the Eastern Dharwar craton based on $U-P b$ zircon geochronology, Nd isotopes and whole rock geochemistry. Her research interests include characterization of different components Archaean basement gneisses and granitoids using elemental and tracer isotopes.

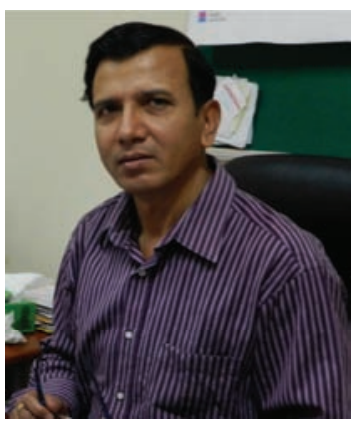

M.Jayananda is currently working as Professor at University of Delhi and as Editor of Episodes. He has conducted multidisciplinary research on Precambrian basement geology including magmatism and continental growth, time scales of metamorphism and tectonic processes. He has spent several years at Universite de Rennes I (France) and Yamaguchi University (Japan) mainly working on zircon geochronology, whole rock geochemistry and $\mathrm{Nd}$ isotopes on Precambrian basement complexes of southern India. His research interest includes magmatism, tectonics and continental growth through time. 